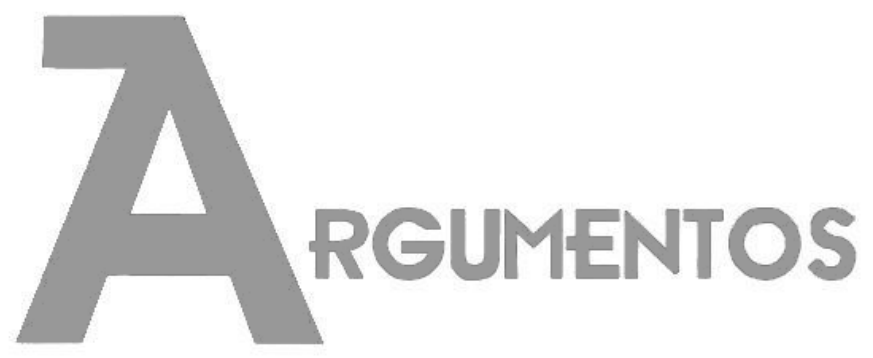

Vol. 16, n. 2, jul./dez. 2019 ISSN: 2527-2551 (online)

A sociedade de curral:

\title{
desenvolvimento social pelas figurações sociais, pelo habitus e pela organização do estado no Norte de Minas ${ }^{1}$
}

\author{
João Batista de Almeida Costa²
}

Recebido em: 21/02/2019

Aprovado em: 18/07/2019

\begin{abstract}
Resumo: O processo civilizador da sociedade norte mineira é abordado na leitura que construo, tendo a perspectiva teórico-metodológica de Norbert Elias como base para a leitura das redes de inter-relações organizadas por interdependências que no conjunto propiciam o caráter da formação social desta sociedade. O desenvolvimento social pode ser apreendido e compreendido em sua duração e nos ritmos da própria transformação de uma formação social. Para tanto, há duas vertentes que devem ser percorridas: por um lado, o pólo de organização em suas propriedades fundamentais e estruturais em que as posições e relações existentes são independentes dos indivíduos que as ocupam nas funções que se acham inseridos nas relações; por outro lado, o desenvolvimento do habitus, ou seja, saber social incorporado pelos indivíduos, que no equilíbrio entre mudanças e continuidades, dão o tom característico do processo civilizador que é intimamente vinculado ao processo de formação do Estado a que a sociedade foi submetida. A leitura construída focaliza na partida as figurações que articulavam indígenas entre si e com quilombolas, para, depois, realizar o percurso da Sociedade de Curral desde seus primórdios em meados dos anos 1660, até os anos 1970.
\end{abstract}

Palavras-chave: Sociedade norte mineira, processo civilizador, desenvolvimento social, habitus.

La sociedad de curral: desarrollo social por figuraciones sociales, por el hábitus y por la organización del estado en el Norte de las Minas

Resumen: El proceso civilizador de la sociedad norte mineira se aborda en la lectura que construyo por la perspectiva teórico-metodológica de Norbert Elias que se toma como base para leer las redes de interrelaciones organizadas por interdependencias que en conjunto

\footnotetext{
1 Agradeço aos colegas Cláudia Luz de Oliveira e Camilo Antônio Silva Lopes pelas contribuições nos diálogos realizados a pós leitura da argumentação construída e a Mercês Antoni eta de Almeida Costa pelas correções gramaticais.

${ }^{2}$ Antropól ogo, professor e pesquisa dor no Programa de Pós-Graduação em Desenvolvimento Social e no curso de Ciências Sociais da Universidade Estadual de Montes Claros (Unimontes), Brasil. E-mail: d.jobacosta@gmail.com. ORCID: http://orcid.org/000.0001-5642-1398.
} 
proporcionan el carácter de la formación social de esta sociedad. El desarrollo social puede ser incautado y comprendido en su duración y en los ritmos de la transformación misma de una formación social. Para ello, hay dos aspectos que deben cubrirse: por un lado, el polo de la organización en sus propiedades fundamentales y estructurales en las que las posiciones y relaciones existentes son independientes de los individuos que las ocupan en las funciones que se insertan en las relaciones; por otro lado, el desarrollo del hábitus, es decir, el conocimiento social incorporado por los individuos, que en el equilibrio entre cambios y continuidades, dan el tono característico del proceso civilizador que está estrechamente vinculado al proceso de formación del Estado al que la sociedad estaba sometida. La lectura construida enfoca, al principio, las figuraciones que articulaban a los indios entre sí y con quilombolas, para luego llevar a cabo el curso de la Sociedad Curral desde sus inicios a mediados de la déca da de 1660 hasta la década de 1970.

Palabras-clave: Sociedad norte mineira, proceso civilizador, desarrollo social, habitus.

\title{
The curral society: social development by social figurations, habitus and the state organization in the North of Minas
}

\begin{abstract}
The civilizing process of the norte mineira society is approached in the reading that I construct having the theoretical-methodological perspective of Norbert Elias as a base for the reading of the networks of interrelations organized by interdependencies that in the whole propitiate the character of the social formation of thissociety. Social development can be seized and understood in its duration and in the rhythms of the very evolution of a social formation. For this, there are two aspects that must be covered, on the one hand, the pole of organization in its fundamental and structural properties in which the existing positions and relations are independent of the individuals who occupy them in the functions that are inserted in the relations. And, on the other hand, the social development like the habitus, that is, social knowledge embodied by individuals who in the balance between changes and continuities give the tone characteristic of the civilizing process that is closely linked to the process of formation of the state to which society was subjected. The constructed reading focuses, in the beginning, the figurations that articulated indigenous among themselves and with quilombolas, to later realize the course of the corral society from its beginnings in the middle of the years 1660 until the years 1970.
\end{abstract}

Keywords: Norte mineira society, civilizing process, social development, habitus.

\section{Introdução}

A leitura que desenvolvo apoia-se na perspectiva teórico-metodológica de Norbert Elias (1997) para quem o objeto de estudo sociológico são as redes de interrelações, as interdependências, as figurações e os processos formados pelos homens interdependentes. Alicerçado nesta perspectiva, procuro desenvolver aqui uma leitura do processo civilizador do Norte de Minas tomado como uma formação social, para ler em seu desenvolvimento social as relações que vinculam diferentes sujeitos entre si e tendo na vivência das relações estabelecidas o habitus, como o chão que organiza a vida na sociedade norte mineira. Como saber social incorporado, o habitus é dinâmico no tempo, implicando equilíbrio entre continuidade e mudança. 
A utilização do conceito de figuração possui dimensões variáveis que pode ser aplicado desde uma mesa de jogadores de baralho à nação, como informa Elias (1997), dado que ela se constitui como formação social em que os indivíduos estão ligados entre si de modo específico de dependências recíprocas. A reprodução da formação social supõe um equilíbrio de tensões e a variabilidade ocorre nas cadeias de interdependência que definem a especificidade de cada figuração social. Para se desenvolver a leitura do desenvolvimento social de uma formação social, o foco principal deve ser coloca do nas mudanças estruturais da sociedade como um todo, que se vincula às especificidades de cada formação, sempre considerando como se articulam as figurações que estruturam a vida social nela ocorrente.

Ao descrever o desenvolvimento social norte mineiro, parto dos antecedentes da emergência dessa sociedade, passando por sua constituição como formação sóciohistórica, econômica e cultural específica, até chegar, sem ler tal processo, ao momento da modernização da economia nacional. E no caso particular, da expansão capitalista de produção nos anos 1960, quando a sociedade norte mineira passa a ser vinculada à área de atuação da Superintendência de Desenvolvimento do Nordeste, por ser parte do Polígono das Secas, e, por meio da qual se verificaram as principais mudanças estruturais nas figurações sociais modeladas pelas figurações emergentes. Procuro ler ainda que de modo ensaístico, o processo civilizador norte mineiro focalizando o seu desenvolvimento social, na perspectiva desenvolvida pelo sociólogo cuja teoria me orienta nesta escrita.

Considero que o processo civilizador norte mineiro pode ser compreendido em dois momentos distintos: o primeiro vinculado à sua emergência como formação histórica específica no contexto colonial com uma economia agropastoril instaurado desde meados do século XVII até meados do século XX. Nesse percurso temporal, diversos rearranjos internos podem ser verificados e apreendidos pela manutenção da estrutura do padrão figuracional a que denomino sociedade do curral, ainda que agregando novas individualidades.

Em meados do século $X X$, dada as mudanças estruturais que ocorrem na sociedade brasileira, emerge uma nova figuração com a entrada de outras individualidades para além daquelas existentes até então. Muitas dessas individualidades, como dito por Santos (1997), não se encontram situadas no interior da 
sociedade norte mineira, mas dispersas pelo país e em outros estados nacionais, dada a característica globalizante do sistema econômico hegemônico mundial. Esta leitura não será desenvolvida aqui.

E, para dar um fim a essa introdução, informo que a Sociedade Norte Mineira considerada por mim, não se vincula às regiões administrativas que são classificações do Estado para gerenciar a economia e a política em Minas Gerais. Refiro-me, portanto, à região onde o gado se estendeu a partir de meados do século XVII, os chamados Currais do São Francisco, que ultrapassam as atuais fronteiras administrativas e nos quais os processos sociais, econômicos e políticos estiveram subsumidos à cul tura do curral que alimentou as minas gerais, as minas goianas e mato-grossenses e que desde então deram significações a sua vida cultural.

Importante salientar que a leitura apresentada tem início durante a graduação em Ciências Sociais, amplia-se quando funcionário do Estado como técnico de desenvolvimento, então apreendo a existência de lógicas diferenciadas e conjugadas na cultura sertaneja (COSTA, 1997), perpassa minha formação como antropólogo na pósgraduação encerrada com a discussão da configuração que engloba, exclui e que expulsa o sujeito norte mineiro para um entre-lugar (COSTA, 2017) e permanece sendo desenvolvida nas pesquisas realizadas por mim e pelos colegas da Universidade Estadual de Montes Claros ${ }^{3}$.

\section{Anterioridade ao alvorecer da Sociedade de Curral}

No espaço geográfico em que a sociedade, hoje denominada norte mineira, emergiu a partir de meados do século XVII coexistiram, conforme informação de Senna (1926) dezesseis sociedades indígenas fixadas às margens e ilhas do rio São Francisco e seus afluentes, no planalto divisor das bacias desse rio com o Jequitinhonha, na nascente e curso alto do rio Pardo. Esse autor baseou-se em documentação colonial para apreender e situar todas as sociedades indígenas que ocupavam o espaço geográfico de Minas Gerais. Como essas sociedades não foram estudadas, a

\footnotetext{
3 Para conhecimento da produção acadêmica realizada por mim, consulta a Plataforma Lattes: http://buscatextual.cnpq.br/buscatextual/visualizacv.do?id=K4768381D8
} 
Artigo |A sociedade de curral: desenvolvimento social pelas figurações sociais, pelo habitus e pela organização do estado no Norte de Minas (COSTA, João Batista de Almeida)

compreensão da figuração de cada uma delas pode ser apreendida a partir de estudos antropológicos sobre populações indígenas.

Em seu vasto estudo sobre áreas etnográficas, Júlio César Melatti ${ }^{4}$ possibilita afirmar que o espaço da sociedade norte mineira foi ocupado por sociedades do tronco lingüístico Macro-Jê e denominadas pelas populações regionais como tapuias, cuja classificação era de origem tupi-guarani para os povos estrangeiros, ou seja, os MacroJê, perspectiva semelhante com que os gregos denominavam bárbaros aos falantes de outras línguas diferentes.

A figuração social nos grupos indígenas articula os indivíduos entre si organizava se por dependências recíprocas como discutido pelo mesmo autor em seu livro Índios do Brasil (Melatti, 1993). Nesse livro são apresentados diversos aspectos da especificidade cultural dessas sociedades, considerando a organização social, a vida política, a produção de alimentos, bem como o trabalho e as relações sociais. Considero que é possível apreender nessas informações o caráter figuracional das dezesseis sociedades indígenas que ocuparam o espaço médio do rio São Francisco, até a chegada de Mathias Cardoso de Almeida e sua bandeira nos anos 1660, conforme Paes (1980).

A organização social que existia em cada aldeia formada por grupos familiares, metades, clãs e linhagens unindo homens e mulheres. Os casamentos se devam no interior da aldeia quando há metades, clãs e linhagens ou entre aldeias de uma mesma sociedade. Há o interdito sexual, ou seja, a proibição do incesto no interior de uma aldeia formada por um mesmo clã ou linhagem definindo o casamento exogâmico de aldeia e de clã ou de linhagem.

Em sua obra, Melatti afirma que "entre os índios do Brasil, a maior unidade política é a aldeia; cada aldeia é politicamente independente: não reconhece nenhuma autoridade mais alta que a de seu chefe" (1993, p. 109). A vida política se organiza com uma chefia e um conselho de anciãos. O chefe é um primus inter pares, ou seja, ele não tem o mando como conhecemos. Tomada a decisão no conselho dos anciãos ou de lideranças das famílias extensas que vivem na aldeia, ele deve ser o primeiro a executar o que foi acordado por todos. Sua liderança é sempre cautelosa, dado haver membros

\footnotetext{
${ }^{4}$ http://www.juliomelatti.pro.br/areas/a1amersul.pdf, consulta do em 13/10/2018.
} 
Artigo |A sociedade de curral: desenvolvimento social pelas figurações sociais, pelo habitus e pela organização do estado no Norte de Minas (COSTA, João Batista de Almeida)

que não são seus partidários e estão sempre prontos a desafiá-lo para tomar-lhe o poder.

A produção de alimentos é vinculada às atividades de caça, pesca, coleta, plantio e criação de animais, que requerem a fabricação de instrumentos de trabalho, transporte e a guarda ou conservação dos mesmos. A divisão do trabalho é dada pelo sexo e não há profissionalização no interior de uma aldeia, cada um sabe o que todos os outros sabem, sejam homens ou mulheres. Às mulheres cabem atividades culinárias e cuidados com as crianças e, aos homens, as atividades guerreiras, a caça, a derrubada da floresta para se fazer a lavoura e, juntos, partilham atividades de plantio e colheita.

Figuracionalmente, então, as sociedades indígenas se articulavam para a atividade laboral e para a atividade política, sendo que na primeira os homens se vinculavam às mulheres cada um com atividades específicas ou compartilhadas. E na segunda, a chefia se vinculava ao conselho de anciãos ou de famílias extensas e aos demais membros da aldeia. Como cada aldeia era uma figuração social específica, os indivíduos detinham funções precípuas para o bem-estar do grupo a que pertencia, como um todo. Entretanto, em decorrência das relações interétnicas, cada aldeia se vinculava com outras e, mesmo, com membros de sociedades distintas.

As diversas sociedades indígenas que aqui existiram não se encontravam isoladas umas das outras, mas se articulavam em totalidades sociais hierárquicas ou simbióticas, conforme Ramos (1994). Em seu estudo sobre relações interétnicas, Ramos (1980), informa a existência de relações assimétricas de status que se opunham, ocorrendo relações de sujeição e dominação. E por sociedade simbiótica essa mesma autora informa a ocorrência de complementaridade de relações entre as etnias vinculadas em condições de igualdade. Seja em arranjos hierárquicos ou simbióticos, os grupos indígenas sempre estabeleceram trocas de produtos, de uniões matrimoniais, dentre outras. E no confronto com as frentes de colonização se articularam para a defesa de seus territórios e de seus modos de vida.

Na região do médio sanfranciscano ocorreu, a partir de meados dos anos 1640, o estabelecimento de assaltos de grupos indígenas para obstaculizar a penetração da colonização no Recôncavo Baiano, conforme informado por Taunay (1948). Essa ação revela a vinculação das sociedades indígenas entre si e com os grupos aquilombados que existiam na área. A Capitania da Bahia, frente aos incêndios nos canaviais dessa 
Artigo |A sociedade de curral: desenvolvimento social pelas figurações sociais, pelo habitus e pela organização do estado no Norte de Minas (COSTA, João Batista de Almeida)

área, convoca bandeiras da Vila de São Paulo para aprearem indígenas que, posteriormente, eram submetidos à escravidão e oxtermínio dos quilombolas para dar um fim aos ataques e aos incêndios, com os quais os revoltosos tentavam impedir o avanço da colonização portuguesa.

Os quilombos que existiram no período anterior à chegada da bandeira paulista que ocupou a região se organizavam por pequenos agrupamentos de africanos e seus descendentes que, fugindo da escravidão, deram origem a moradias situadas, principalmente, mas não exclusivamente, no interior da floresta de caatinga arbórea existente no vale do rio que, posteriormente, passou a ser denominado como Verde Grande.

Duas dinâmicas distintas definiam a área escolhida pelos africanos e seus descendentes fugidos da escravidão nas diversas regiões do Brasil e mesmo das Américas. Conforme informado por Carvalho (1996), por um lado a busca de espaços que obstaculizasse qualquer contato com a sociedade escravocrata e, para tanto, escolheram lugares que fossem áreas que os índios não habitassem. Por outro lado, a manutenção de alguma forma de contato com a sociedade escravocrata e, para tanto, fixavam-se em áreas que os portugueses e seus descendentes recusavam por alguma razão, mas nas proximidades de arraiais, vilas e cidades, como discutido por Gomes (1996).

De uma forma ou de outra, os quilombos estavam resguardados por barreiras estruturais, ou seja, a existência de algum impedimento para o estabelecimento de relações desde fora, seja por questões naturais, como a existência de malária, de corredeiras e cachoeiras, serras íngremes, furnas ou vãos, nos cafundós do judas dentro de florestas, ou seja, por questões sociais, terras que não tinham nenhum valor econômico, principalmente. Em decorrência da estratégia da invisibilidade para não ser percebido por capitães do mato ou dos senhores de escravo, pouco impacto causavam no manuseio da vegetação onde se fixavam.

A organização social de cada quilombo, conforme se pode fazer ilação a partir de relatos de diversos viajantes europeus pela região, dava-se pela articulação da mulher com seus filhos, fixada em algum ponto do território, enquanto os homens circulavam entre um local e outro. Não é possível afirmar a existência de autoridade, a não ser a materna, dada a sua fixação com seus descendentes no entorno de lagoas ou de 
pequenos cursos de água. Assim, a divisão sexual do trabalho legava à mulher as atividades que viabilizassem a alimentação do grupo e o homem criando animais soltos na $\operatorname{larga}{ }^{5}$, caçando e pescando, percorria o território para defesa da família.

Nesse espaço intersocietário, os africanos e seus descendentes desenvolveram algum tipo de produção agrícola, pecuária e extrativista. As comunidades existentes no vale do rio Verde Grande, em decorrência da presença de um grande número de lagoas formadas nas dolinas, regionalmente conhecidas como furados, no interior da floresta de caatinga arbórea, com umidade em suas margens, propiciavam o cultivo de produtos agrícolas, notadamente, mandioca, milho, arroz, feijão e fava, banana, dentre outros produtos, como na descrição de Velloso (1901). A este tipo de cultivo, os descendentes desses quilombolas históricos denominam, ainda hoje, como agricultura de furado.

O gado bovino era criado solto no interior da floresta possibilitando, posteriormente, dar origem a diversas localidades com denominação de Gado Bravo, Gado Velhaco, Barreiro do Rio Verde, Barreiro da Raiz ${ }^{6}$, dentre outras. As diversas pequenas comunidades mantinham entre si vínculos sociais para a proteção do território negro e para festejar seus santos e suas relações, como dito por Neves (1908). Estes vínculos estruturavam redes de parentescos no interior de cada quilombo e entre quilombos, que também eram chamados de mocambos ou calhambos.

E, como afirmado acima, no alvorecer da colonização da área, a união com grupos indígenas que se deslocavam até o Recôncavo Baiano para colocarem fogo nos canaviais e, também, como informado no estudo dos Xacriabá realizado por Santos (1997), ocorriam outros tipos de vinculação. Essa autora informa a existência de contatos entre antigos membros dessa sociedade indígena e de negros aquilombados no interior da floresta de caatinga arbórea existente no vale do rio Verde Grande.

Essa informação nos permite afirmar a existência de alguma forma de vínculos entre indígenas e quilombolas, muito mais numa pers pectiva de simbiose do que numa perspectiva hierárquica. Nesse sentido, Costa Silva (1998), estudando o Quilombo de Rio das Rãs, situado no território baiano nas proximidades de Bom Jesus da Lapa e

\footnotetext{
${ }^{5}$ A larga refere-se comumente a deixar os animais pastarem soltos pelas chapadas dos gerais e no vale do rio Verde Grande.

${ }^{6}$ Diversas áreas com alto teor de salinidade são, regionalmente, denominadas de barrei ros e eram lugares onde o gado acorria para lamber o solo.
} 
Artigo |A sociedade de curral: desenvolvimento social pelas figurações sociais, pelo habitus e pela organização do estado no Norte de Minas (COSTA, João Batista de Almeida)

constituinte da mesma formação negra do vale verdegrandense e da mesma formação social que instituiu os Currais do São Francisco, informa a existência de vinculações entre populações não-brancas, conformando uma imensa sociedade com uma racionalidade baseada na reciprocidade e na solidariedade onde a competição e a concorrência entre grupamentos étnicos distintos não se verificava.

Com a chegada dos bandeirantes, inicia-se a construção de um espaço social branco com a presença de territorialidades étnicas distintas, indígenas e quilombolas, organizada por relações de parentesco e casamento, por relações de escravidão e servidão, hierarquizando as posições sociais da formação social que emergia na história.

Em resumo, podemos dizer que antes da chegada dos portugueses e seus descendentes, existia na área média da bacia do rio São Francisco uma sociedade multicultural e multiétnica, organizada pelos princípios de reciprocidade e solidariedade, com relações sociais articuladas fortemente por parentesco e, possivelmente, por casamento interétnico por ser esta uma característica das sociedades indígenas brasileiras.

Assim, consolidou-se nesta área sanfranciscana uma sociedade de encontros e de liberdade, que não era tardia, porque verificada na prática social e cuja característica é legada à sociedade que se forma com a presença dos brancos. Cada grupo étnico articulava figuracionalmente homens e mulheres entre si, a liderança, o conselho de anciãos ou de famílias extensas, e com outras aldeias em relações de aliança estabelecidas por meio do casamento exogâmico de aldeia.

Com a chegada de africanos e/ou seus descendentes fugindo à escravidão para viverem com liberdade e garantirem a autonomia de suas vidas, outra possibilidade de aliança foi o casamento interracial. Os quilombolas figuracionalmente se articulavam entre homens, mulheres e seus descendentes. No caso dos grupos situados no interior da mata do vale do rio Verde Grande, do ponto de vista político, entre a liderança feminina e seus descendentes vivendo sob seu domínio ou nas proximidades de sua localização e, por outro lado, com seus parceiros que circulavam todo o território nãobranco.

Dessa forma, podemos afirmar que a configuração existente antes da chegada da bandeira paulista a partir de meados dos anos 1660, tinha como característica a interetnicidade, porém, sem centralização de poder político e sem autoridade central. 
Entretanto, as individualidades indígenas e quilombolas se articulavam entre si em momentos de conflitos para obstaculizar a penetração da colonização portuguesa, como afirmado anteriormente.

A característica cultural da configuração social existente antes da chegada da bandeira de Mathias Cardoso de Almeida, multicultural e multiétnica permanece na vigência da sociedade de curral em decorrência das formas como as gentes se apropriaram das diversas ecologias onde os biomas cerrado, caatinga e floresta tropical úmida se encontram e transitam entre si. Essa pespectiva é atualizada, ainda que ocorra uma complexificação social mais abrange, pelo reconhecimento do Brasil como nação pluriétnica e multicultural na Constituição de $1988^{7}$.

\section{A Sociedade de Curral: emergência e consolidação}

Nos anos de 1660, Mathias Cardoso de Almeida se deslocou para o médio curso do rio São Francisco, com parte dos membros da bandeira que chefiava, em atendimento à convocação da Capitania da Bahia, em sua luta contra indígenas e quilombolas revoltosos. Nesse período ele herdou do pai, Mathias Cardoso de Almeida, alcunhado $\mathrm{O}$ Velho, a bandeira familiar e passou a ter o comando sobre a mesma.

A convocação da Capitania da Bahia impunha como objetivo guerrear, aprear indígenas e exterminar quilombos, como forma de apaziguar a região do Recôncavo Baiano que sofria com os incêndios dos canaviais, conforme Paes (1980 e 1980a). Conhecedor das características da área do médio São Francisco, o chefe da bandeira transfere-se com seus familiares e liderados para as margens do rio Verde Grande nas proximidades de sua foz e dá início à luta contra indígenas e quilombolas articulados entre si para lutar contra a interiorização da colonização portuguesa desde o Recôncavo Baiano.

Após se fixar às margens do rio Verde Grande e, posteriormente do rio São Francisco, Mathias Cardoso de Almeida distribuiu os membros da bandeira por diversas localidades, iniciando, assim, a ocupação da área, a organização da sociedade que no

\footnotetext{
7 Como dito anteriormente, tanto na formação como cientista social e como antropólogo, bem como nos estudos e pesquisas desenvolvidos posteriormente, como pode ser verificado nas várias publicações pessoais ou com colegas sobre todas as temáticas aqui tratadas.
} 
Artigo |A sociedade de curral: desenvolvimento social pelas figurações sociais, pelo habitus e pela organização do estado no Norte de Minas (COSTA, João Batista de Almeida)

período emerge no interior da Colônia e atende ao objetivo da convocação do governo baiano. Por duas vezes foi chamado à Vila de São Paulo: na primeira para acompanhar seu tio Fernão Dias Paes em busca das esmeraldas no ano de 1674 , ocasião em que trouxe cabeças de gado para serem criados nas fazendas que instalaram nas localidades que se fixaram e, para executar tal função é nomeado Capitão-Mor na caminhada do tio. E a segunda, para acompanhar o representante espanhol, dada a vinculação de Portugal ao reino de Espanha com a ausência de herdeiro real para o trono lusitano, Don Rodrigo Del Castel Blanco em 1680, em sua expedição de reconhecimento ao Sertão dos Cataguá. Para tanto foi nomeado Tenente-general, ocasião em que tomou conhecimento de estratégias e táticas de guerra.

Seu irmão Manoel Cardoso de Almeida recebe patente, em 1679, com a finalidade de plantar roças no percurso da viagem do representante espanhol. Se na primeira ocasião ele abandona o grupo de seu tio deixando diversos serviçais para retornar ao seu arraial; na segunda, após Don Rodrigo Del Castel Blanco ser assassinado na Barra do Guaicuhy por Borba Gato, também retorna à região onde os membros da bandeira comandada por ele tinham se fixado e estavam implantando fazendas com criação de gado e atividade agrícola.

Em digressão baseada em Carvalho Franco (1940), Taunay (1948) e Putoni (2002) é informado que em 1689 a Câmara da Vila de São Paulo indica o chefe da bandeira fixada nas margens do rio Verde Grande e rio São Francisco para comandar grupos combatentes contra os indígenas que guerreavam buscando obstaculizar a penetração da colonização portuguesa no Nordeste Brasileiro. Na chamada Guerra dos Bárbaros e, também Confederação dos Kariri, Mathias Cardoso de Almeida requer a submissão de todos os corpos de guerra das capitanias nordestinas a seu mando. Recebe, então, a patente de Governador Absoluto e a patente de Mestre de Campo. No comando sob dois corpos de guerra, utiliza as estratégias aprendidas com o representante espanhol. Requer ao Governo Geral a fundação de uma vila em seu arraial.

Em 1696, tendo alcançado o objetivo para o qual fora contratado, impor derrota às vinte e sete sociedades indígenas confederadas e expulsar os membros que restaram para outras áreas menos povoadas, retorna ao seu arraial e vai a São Paulo para acompanhar a ida dos familiares dos membros dos corpos de guerra que lutaram sob seu comando no Nordeste e, assim, mais paulistas se transferiram para a área sob seu 
Artigo |A sociedade de curral: desenvolvimento social pelas figurações sociais, pelo habitus e pela organização do estado no Norte de Minas (COSTA, João Batista de Almeida)

comando, ampliaram a povoação do médio curso sanfranciscano e consolidaram a sociedade que sua bandeira deu fundação. É então nomeado Governador dos Índios do São Francisco e recebe uma sesmaria da nascente do rio Pardo à nascente do rio Doce. Com sua morte em 1707, seu filho Januário Cardoso de Almeida assume a Governança dos índios do São Francisco.

As bandeiras eram organizações coletivas que articulavam membros de uma família, seus agregados e escravos, notadamente indígenas, conforme discutido por Ricardo (1956). Para o autor do pequeno ensaio de bandeirologia, a bandeira paulista foi "o primeiro grupo em que se operam na colônia a solidariedade social mais ampla do que a da família, não faltando exemplos do seu feitio nitidamente comunitário" (1956, p. 66). Por sua vez, Paes (1980a) informa que a organização comunitária comandada por Mathias Cardoso de Almeida e posteriormente Januário Cardoso de Almeida se dispersou por diversos pontos da região.

Entre as funções da Governança dos Índios do São Francisco executada por Mathias Cardoso de Almeida e, posteriormente, por seu filho Januário Cardoso de Almeida, além de manter a pacificação no curso médio sanfranciscano, havia o recolhimento do dízimo que, anualmente, era entregue pelo governador à Capitania da Bahia ou enviado ao Conselho Ultramarinho em Portugal. Nas semanas santas, todos os membros da organização social iniciada com a bandeira, deslocavam-se para Morrinhos onde foi instalada a Freguesia de Nossa Senhora da Conceição em 1695. Quando se encontravam, prestavam suas obrigações religiosas, atualizavam as relações sociais e políticas e apresentavam ao governador as contas do dízimo e lhe entregavam o valor informado. Nesse período há diversos arraiais distribuídos tanto às margens dos rios das Rãs, Verde Grande, Verde Pequeno, Pardo, Gurutuba e São Francisco, todos eles vinculados ao Governo dos Índios do São Francisco.

As fazendas estavam organizadas para a produção de alimentos e para o criatório do gado, cuja produção neste período era comercializada com a sociedade do Recôncavo Baiano e a Soteropolitana, conforme discutido por Abreu (2000) e Prado Junior (2000). A economia que se forma ao longo do rio São Francisco atende à economia canavieira baiana, com a alimentação necessária para que a mesma se dedicasse à produção de açúcar, primeiro produto agrícola exportado para Portugal que estabeleceu comércio com os reinos europeus. 
Artigo |A sociedade de curral: desenvolvimento social pelas figurações sociais, pelo habitus e pela organização do estado no Norte de Minas (COSTA, João Batista de Almeida)

Em sua dissertação de mestrado Anastasia (1983) informa que o sistema de produção que se consolidou no sertão sanfranciscano constituiu-se como a emergência da economia privada na Colônia Brasil tendo a função de abastecimento do mercado interno.

Com a descoberta do ouro e a fixação de Manoel Nunes Viana como procurador da Casa da Ponte, há uma maior complexificação da sociedade que emergiu no curso médio do rio São Francisco e, também, o estabelecimento da relação comercial com as minas gerais onde se deu a exploração aurífera, conforme discutido por Barreiros (1984) e Antonil (1997). Nesse período, em decorrência da descoberta de ouro em Goiás e Mato Grosso há um deslocamento de fazendas para essas regiões auríferas e o estabelecimento do comércio com os mineradores das duas áreas. Como o pagamento dos produtos alimentícios (agrícolas e da pesca), dos gados vendidos em pé e dos animais de carga e tração era feito em ouro, Portugal proíbe o comércio entre as duas regiões e manda fechar os caminhos para a Bahia (cabe lembrar aqui que neste período a Capitania da Bahia ia até a foz do rio Vaihun, atual rio Paraopeba ${ }^{8}$, situado à montante da atual cidade de Pirapora). A essa ação há denominações pejorativas, ainda utilizadas pelos historiadores e nos estudos das relações entre as duas regiões, como contrabando do ouro, isolamento regional, principalmente 9 .

Liderados por Manuel Nunes Viana, os criadores de gado do médio sanfranciscano, organizam o conflito denominado Guerra dos Emboabas, para que os paulistas perdessem o domínio das minas, lavras e catas na região mineradora. Em decorrência da vitória, cujo domínio dos chamados baianos durou um curto período, conforme discutido por Barreiros (1984) é posto um fim à exclusividade paulista na atividade mineratória. O Governador dos Emboabas retorna à fazenda na região do rio

\footnotetext{
8 Pires (1979) ao discutir as raízes de Minas informa que o rio Vaihun que dava limite sul à Capitania da Bahia é o rio Paraopeba, cuja nascente próximo a Ouro Preto, no município de Cristiano Ottoni, deságua na represa de Três Marias, do rio São Francisco no município de Felixlândia.

${ }^{9} \mathrm{Na}$ perspectiva da colonialidade do saber, conforme discutido por Bhabha (1998) há uma linguagem da dominação que apenas a desconstrução da história a partir da perspectiva do subalterno pode trazer à luz o real conteúdo da significação. Nunca houve contrabando do ouro, dado o comércio entre a região pastoril e a região mineradora pelo abastecimento de alimentos e de animais de tração e carga. Assim como não houve isolamento, pois os caminhos não foram fechados, conti nuando a ocorrer o comércio com a região minera dora já sob o monopólio de Portugal e, ta mbém, o es tabel ecimento do comércio com as regiões auríferas de Goiás e Mato Grosso.
} 
Artigo |A sociedade de curral: desenvolvimento social pelas figurações sociais, pelo habitus e pela organização do estado no Norte de Minas (COSTA, João Batista de Almeida)

Carinhanha e passa a administrar os bens fundiários da Casa da Ponte arrendando diversas áreas, conforme discutido por Pires (1979) e ampliando a ocupação da área.

Tentando colocar um fim ao domínio do comércio entre o sertão e as minas generalizadas no entorno do pico Itacolomi, o Conselho Ultramarinho em Portugal no ano de 1720 incorpora a margem direita do rio São Francisco até a foz do rio Verde Grande e seus afluentes à região mineradora, instituindo a Capitania de Minas Gerais. Ao mesmo tempo institui a mudança da cobrança de imposto que passa de pagamento anual do dízimo para a cobrança do quinto em cada transação comercial com a implantação dos locais de contagem e dos currais d'el rei.

Após infrutíferas tentativas de Januário Cardoso de Almeida, então Governador dos Índios do São Francisco, do retorno do pagamento do dízimo como imposto anual, algumas lideranças organizam uma revolta que passou, na linguagem do colonizador e dos historiadores mineiros como motins do sertão, e na linguagem subalterna dos historiadores norte mineiros como conjuração sanfranciscana, conforme Braz (1977). O governo da capitania mineira impõe, então, mais restrições ao comércio entre o sertão sanfranciscano e a região das minas generalizadas. Após o aprisionamento das lideranças, muitos membros das famílias se transferiram para a Capitania da Bahia ou retornaram a Capitania de São Paulo, dada a possibilidade de maior ganho em suas atividades produtivas devido a nelas vigorar o pagamento do imposto pelo dízimo, anualmente.

As fazendas fundadas pelos membros das bandeiras eram administradas pelos seus fundadores com mão de obra escrava, notadamente de indígenas, como informado por Paes (1980a). E, também, havia fazendas cujos donos, absenteístas, moravam nas vilas e cidades do litoral e mantinham empregados criando gado e produzindo alimentos, conforme estudo de Prado Junior (2000).

Nessa segunda perspectiva, o vaqueiro recebia como ganho por seu trabalho vinte e cinco por cento do gado nascido em quatro anos, retirada dessa porcentagem o número de cabeças recebidas e, aos poucos, foram propiciando a criação de uma camada social de médios fazendeiros que se apossavam de terras não ocupadas e nelas fixavam seus parentes, conforme estudo de Rocha (1983).

Entretanto, um grupo muito grande de gente miúda ocupou as terras do sertão sanfranciscano, ainda que tenha havido contra os mesmos tentativas de submetê-los ao 
Artigo |A sociedade de curral: desenvolvimento social pelas figurações sociais, pelo habitus e pela organização do estado no Norte de Minas (COSTA, João Batista de Almeida)

domínio das fazendas. Primeiramente, os membros de sete sociedades indígenas que vindos da região goiana e matogrossense se fixaram em diversos lugares da região. Januário Cardoso de Almeida, como Governador dos Índios do São Francisco fez um acordo com os índios Xakriabá que foram os primeiros a chegar e os armaram para fazerem guerra contra indígenas de outras sociedades que se deslocaram para a margem esquerda do rio São Francisco, como Kayapó, Xerente, Krixá, Xikrin, dentre outras. A estratégia de articular-se com indígenas para expulsar os chegantes foi vitoriosa e como resultado da ação os Xakriabá receberam em 1728 uma área de terra por doação do Januário Cardoso de Almeida, conforme Santos (1997).

No interior do vale do rio Verde Grande coberto com vegetação de caatinga arbórea e com a presença de milhares de lagoas, os africanos e seus descendentes que fugiram à escravidão e se fixaram na área também desenvolveram atividades produtivas, em escala reduzida, o suficiente para o abastecimento familiar. Essa gente manteve relações com as povoações situadas às margens do rio São Francisco ou nas encostas da Serra Geral ou da Serra do Espinhaço.

E, também, famílias portuguesas, espanholas, árabes e judias se fixaram em alguns lugares do território regional, instauraram atividades produtivas assentadas no trabalho familiar e mantinham relações comerciais com as gentes que circulavam pelas águas do rio São Francisco em seu curso médio, conforme Rocha (1983). Muitos dos seus descendentes vão se tornando fazendeiros e comerciantes e se estabelecendo em novas áreas ou se fixando nas vilas que emergem na história regional, a partir do segundo quartel do século XIX.

No estudo sobre a realidade social na região de Montes Claros, Balaio e Ribeiro (1978) e Outros (1987) informam a existência de um número extremamente significativo de pequenos sitiantes e posseiros nas proximidades de pequenas povoações no interior desse território societário que se dedicaram às atividades agropastoris e que se vinculavam, como mão de obra jornaleira, às grandes fazendas que se constituíram na área.

Importante salientarque até esse período a área sanfranciscana estava vinculada à Comarca e à Vila de Serro do Príncipe no alto vale do rio Jequitinhonha e não havia nenhuma organização administrativa, dado o fim imposto à Governança dos Índios quando da criação da Capitania de Minas Gerais em 1720. Sendo assim, cada fazenda 
Artigo |A sociedade de curral: desenvolvimento social pelas figurações sociais, pelo habitus e pela organização do estado no Norte de Minas (COSTA, João Batista de Almeida)

conjugava a função de sua defesa e a autoridade em mãos do patriarca familiar. Nesse período, as fazendas eram, cada uma, um todo englobante, conforme descrito por Araújo (2009), no qual diversas categorias sociais se articulavam de forma interdependente.

O percurso histórico construído até aqui nos permite apreender a configuração inicial do Norte de Minas, desde a chegada e fixação da bandeira de Mathias Cardoso de Almeida nos anos 1660 até a derrota da Configuração Sanfranciscana em 1736. Nesse período, a sociedade que se organizou no curso médio do rio São Francisco foi denominada Currais do São Francisco, que articulavam os Currais da Bahia na margem direita e os Currais de Pernambuco na margem esquerda do rio da integração nacional.

As figurações existentes articulavam, do ponto de vista das relações sociais, senhores descendentes de portugueses que se fixaram na região como bandeirantes e escravos em sua maioria indígenas. Como membros da organização social que os unia, o bandeirismo, objetivaram inicialmente o aprisionamento dos indígenas e o extermínio dos quilombolas que lutavam no Recôncavo Baiano, contra a expansão da colonização portuguesa.

Outra figuração tinha caráter inter-étnico que unia indígenas e quilombolas lutando contra os colonos baianos quando incendiavam os canaviais da Capitania. Com o apaziguamento da área, os bandeirantes como potentados instituíram suas fazendas e incorporaram como agregados os antigos escravos que se tornaram as gentes do eito que labutavam e os escravos domésticos. Assim, a figuração articula fazendeiros e essa gente da labuta que cumpria o papel de lavrador, vaqueiro e pescador.

Há, nesse período, a figura do comerciante e diversos profissionais como pedreiros, marceneiros e ferreiros, muitos deles formados na Escola de Arte e de Ofício implantada por Maria da Cruz, casada com um sobrinho de Mathias Cardoso de Almeida e fixada na localidade de Pedras de Baixo, atual cidade que leva o seu nome. Nesse período, dada a consolidação da povoação, é instaurada a Freguesia de Nossa Senhora da Conceição dos Morrinhos e o clero torna-se presente como uma individualidade, estabelecendo a figuração entre sacerdotes e fiéis.

Há, também, as capelas no Arraial do Meio, no Arraial de Brejo do Amparo, no Arraial de Pedras de Baixo, no Arraial de Pedras de Cima e no Arraial de Santo Antônio da Manga de São Romão. E o aparecimento incipiente do funcionalismo cartorial 
Artigo |A sociedade de curral: desenvolvimento social pelas figurações sociais, pelo habitus e pela organização do estado no Norte de Minas (COSTA, João Batista de Almeida)

hereditário, dada a implantação de um Cartório de Paz, Registro Civil, Tabelionato e Notas desde final dos anos 1690, no arraial da Governança dos Índios do rio São Francisco.

Do ponto de vista administrativo, ainda que a vila solicitada por Mathias Cardoso de Almeida para comandar a guerra contra os indígenas confederados na região do Cariri no Nordeste brasileiro não tenha sido implantada com a Governança dos Índios do Rio São Francisco, havia a articulação do governador com os subordinados, indígenas ou não, sendo que os fazendeiros tinham o lugar hierárquico proeminente nessa figuração. Assim, a configuração inicial da sociedade dos currais articulava agentes produtivos, trabalhadores, religiosos, comerciantes, sacerdotes e funcionários da incipiente organização colonial.

\section{A Sociedade de Curral: a complexificação social, econômica e administrativa}

O século XVIII é encoberto, não há quase nenhuma informação sobre os acontecimentos que ocorreram no passado da sociedade norte mineira, a não ser o s eu papel de fornecedora de alimentos para a região da mineração aurífera e diamantífera. Somente no séculoXIX é que maiores informações podem ser acessadas, principalmente nos relatos dos viajantes europeus, Saint-Hilaire (2000), Mawe (1978), Spix e Martius (1976), Wells (1875), Bernardez (1922) e Burton (1977), que percorreram o chamado país sertão e narraram acontecimentos que permitem esboçar a configuração da Sociedade de Curral em seu segundo momento.

Esses viajantes iniciam em fins dos anos 1810 suas passagens pelo espaço norte mineiro e as encerram em fins dos anos 1890. Há também estudiosos dos fatos ocorridos desde o período colonial nessa região, muitos deles intelectuais regionais, principalmente Abreu (2000), Ambrósio (1934 e 1976), Paula (1957), Viana (1935), Rocha (1983), Lins (1960), Gaspar (s/d), dentre outros, e esparsas informações nas efemérides mineiras de Veiga (1897).

Nos relatos dos viajantes há, recorrentemente, a informação da vida social e econômica baseada na agricultura e pecuária, além do extrativismo vegetal e mineral, notadamente o salitre, atividades econômicas desenvolvidas principalmente por uma 
Artigo |A sociedade de curral: desenvolvimento social pelas figurações sociais, pelo habitus e pela organização do estado no Norte de Minas (COSTA, João Batista de Almeida)

população negra, em sua grande maioria e com número quase insignificante de população branca, como se fora a civilização nilótica, como afirmado por Burton (1977).

Nas análises construídas por esses europeus, cujos relatos fundamentam a sociografia que dá fundamento ao pensamento social brasileiro conforme Souza (1997), a sociedade norte mineira, alcunhada de catrumana, em decorrência da atividade pastoril que dava sustentação à economia da área e, também, ao habitus cavaleiro das gentes, que independente de condição econômica se comportavam com modos brutos e incultos que deveriam ser polidos pela cristianização em seus modos de se comportar, de falar, de comer, de se vestir e de habitar.

Pretensamente isolados da área dinâmica agroexportadora da economia colonial, a sociedade norte mineira se debruça sobre si mesma e mantém vínculos com o Nordeste e com o Centro-Oeste brasileiros em função da expansão das fazendas de gado para as regiões goianas, a comercialização de algodão com a Inglaterra no período da guerra de secessão nos Estados Unidos e o extrativismo e comercialização do látex de mangaba no período do boom da borracha no Brasil.

A produção dessa área se caracteriza por uma agricultura de reprodução da unidade familiar, por uma pecuária extensiva e por baixa circulação de moeda, mas com intensa comercialização de produtos excedentes com as áreas dinâmicas de outras regiões e até mesmo países estrangeiros.

Para o historiador Mata Machado (1991), o Norte de Minas de 1750 a 1947 viveu praticamente de seus próprios recursos ${ }^{10}$. Para este autor, o uso e o beneficiamento de produtos extrativos caracterizavam o modo de vida sertanejo. Eles acessavam nas matas os produtos que precisavam para suprir todo tipo de necessidade e ainda produziam excedentes que comercializavam para outras regiões do país, bem como produção ou extrativismo para comercialização com países estrangeiros. As relações econômicas apoiavam-se em uma economia que se auto-abastecia e que deu origem às unidades produtivas auto-suficientes: as fazendas, circundadas por um conjunto de pequenas unidades de posseiros, agregados e sitiantes. Um todo econômico assentado na conjugação de relações de poder e interdependência, demarcadas por papéis sociais e

\footnotetext{
$10 \mathrm{O}$ a utor denomina seu estudo como a história da região Noroeste de Minas Gerais, mas os dados que dão fundamentação a sua narrativa histórica se refere às diversas áreas que neste ensaio denomino, por sua característica cultural, como Norte de Minas.
} 
Artigo |A sociedade de curral: desenvolvimento social pelas figurações sociais, pelo habitus e pela organização do estado no Norte de Minas (COSTA, João Batista de Almeida)

atravessadas por vínculos afetivos historicamente construídos e por relações de parentesco, de vizinhança e de compadrio, que no seu conjunto, conforme Queiróz (1976) formam a parentela do mando local.

A vida social era organizada em torno do possuidor de terra e, enquanto chefe de família, a autoridade absoluta com exército particular em seus domínios. 0 patriarcalismo constituiu-se, então, sem limites, como o alicerce da organização social de toda a Colônia Brasil, conforme Souza (2017).

No estudo de Ribeiro e outros (1987) sobre a pequena produção rural no Norte de Minas é informada a existência de milhares de famílias, agrupadas ou não em coletividades, coexistindo com os grandes possuidores de terras.

Por outro lado, Costa Silva (1998), afirma a permanência dos não-brancos, ou seja, de sitiantes, nos limites dos territórios patriarcais brancos. E, por sua vez, como dito por Araújo (2009) a fazenda se organiza como modo de vida englobante em que as diversas categorias sociais: fazendeiro, vaqueiro, boiadeiro, sitiante, agregado, posseiro, comerciante nas pequenas povoações, professores, padre e tantas outras que estabeleciam relações de interdependência entre si.

A fazenda, o sítio e as posses eram organizados por um sistema de produção agrícola e pastoril baseado no saber construído historicamente em cada espaço produtivo, com insumos gerados no próprio sistema agrícola, a criação de animais extensivamente com a solta do gado na larga, ou seja, nas chapadas e/ou nas planícies por sua riqueza de pasto, de leguminosas e outras possibilidades de alimentação para os humanos e para o gado. Essas terras eram livres e de apropriação intercomunitária pelos membros das coletividades situadas em seus entornos, vide Oliveira (2017).

No século XVIII, surge na região a atividade mineratória de diamante em Grão Mogol e no século XIX em Jequitaí. São duas formas diferenciadas de exploração mineratória. Enquanto em Grão Mogol a mineração é feita, sobretudo, baseada em mão de obra escrava em pequenas lavras e catas no curso do ribeirão do Inferno e do rio Itacambiruçu. Muitos homens das famílias na região da serra do Espinhaço nas cercanias de Grão Mogol vinculadas à produção agrícola e pastoril, no período da seca se dedicavam à mineração e, ainda hoje, se dedicam como forma de construir uma reserva de valor necessária em momentos de precisão. 
Artigo |A sociedade de curral: desenvolvimento social pelas figurações sociais, pelo habitus e pela organização do estado no Norte de Minas (COSTA, João Batista de Almeida)

Em Jequitaí, a mineração foi feita por famílias às margens do rio de mesmo nome ou com mão de obra escrava, fazendo o cercamento do rio, no período da seca, para mineração em seu leito, por uma multidão de negros e de outras gentes trabalhando como parceiros. Enquanto a mineração na margem era uma atividade masculina, no leito do rio, homens, mulheres, jovens e crianças se dedicavam ao garimpo do diamante.

Há interdependências nessas formas de atividade mineratória, no caso de Grão Mogol, entre o senhor e o escravo e do senhor com o comerciante de diamantes. Nas cercanias dessa cidade entre o lavrador que se faz garimpeiro no período da seca e o comerciante de diamantes. Em Jequitaí, no caso das famílias trabalhando isoladas nas margens do rio, as relações entre pais e filhos assentavam-se na autoridade paterna e deste com o comerciante de diamantes. E no caso do garimpo no leito do rio havia o empreendedor com seus escravos e, também, os garimpeiros que se colocavam como parceiros na busca dos diamantes e do empreendedor com o comerciante de diamantes.

Os comerciantes de diamante se dividiam entre pessoas locais e destes com o principal centro de comércio da pedra preciosa em Diamantina, para onde as produções locais eram deslocadas. No caso de Jequitaí, o Tenente Coronel Cipriano de Medeiros Lima, além de empreendedor, era o comerciante local que adquiria toda a produção diamantífera dos parceiros e das famílias que trabalhavam nas margens do rio, comercializando-a em Diamantina para onde se dirigia recorrentemente para comercialização, também, de produtos agrícolas e pastoris, conforme Pires (2001).

Interessante notar que em Grão Mogol se organizou uma sociedade bastante complexa, dada a existência da atividade agrícola e pastoril, além da atividade mineratória, com a presença de baronato, de maçons e de outras categorias sociais que nela coexistiram, conforme Esteves (1961) e, também, Lasmar e Vasques (2005).

No segundo quartel do século XIX, sete arraiais são transformados em vila conferindo autonomia administrativa às povoações. Assim, o Estado Imperial dá início à sua estruturação no espaço societário norte mineiro. Para tanto, famílias das áreas da mineração vindas de Diamantina, Serro, Gouveia, Conceição do Mato Dentro, Capelinha, Itamarandiba, dentre outras localidades, propiciam a instalação das vilas, dada a necessidade das mesmas serem compostas por "homens de bem", ou seja, descendentes de portugueses. 
Artigo |A sociedade de curral: desenvolvimento social pelas figurações sociais, pelo habitus e pela organização do estado no Norte de Minas (COSTA, João Batista de Almeida)

Essa leva de gente, diversificada em sua condição, deu origem a uma complexificação das posições sociais, com o surgimento de diversos serviços de atendimento às populações e engendra o início da ruptura das relações horizontalizadas nas figurações sociais interdependentes e articuladas entre as categorias sociais vigentes na sociedade norte mineira. Adota, então, comportamentos mais polidos diferenciando a gente branca que chega das populações negras e não-brancas há muito já fixadas na região. Iluminado por Elias e Scotson (2000) posso afirmar que essa nova leva de chegantes dá partida ao processo de construção simbólica que dá origem à relação entre estabelecidos e outsiders, em que os que chegam imputam a si um status superior e aos fixados a condição de inferiores.

O vale do São Francisco, desde o Nordeste até a área norte mineira, passou a produzir algodão que abasteceu as fábricas inglesas durante a guerra de secessão nos Estados Unidos, dando emergência ao estabelecimento de comércio internacional do algodão que propiciou a implantação de um sistema que articulava a produção des se produto, o beneficiamento, o transporte e a comercialização, diversificando a hierarquização das categorias sociais, conforme estudo de Silva (2010). Há o usineiro, os trabalhadores na usina que fazem o beneficiamento do produto, os produtores de algodão e os comerciantes que se utilizando da navegação pelo rio ou pela estrada de ferro e transferem a produção regional para os centros nacionais que demandavam este produto para a confecção de tecidos.

A economia regional engendrou a constituição de um capital econômico significativo que por volta de 1870 é transferido para a Inglaterra com a aquisição de fábricas têxteis por famílias individuais ou por vinculações de famílias entre si, como é o caso de Montes Claros com duas fábricas, de Jequitaí, de Pirapora, de Augusto de Lima, de Rio Pardo de Minas, dentre outras.

As categorias sociais que se vinculavam nesta atividade fabril eram os proprietários das fábricas, os empregados administrativos, os trabalhadores, os representantes das fábricas que vendiam as produções para os comerciantes nas cidades e as mais diversas localidades onde existissem vendas na região.

Nesse período há a instalação de iluminação pública nessas mesmas cidades em decorrência da instalação das fábricas que eram movidas por energia ba seada no carvão vegetal e água. A interdependência existente vinculava os gestores municipais com 
Artigo |A sociedade de curral: desenvolvimento social pelas figurações sociais, pelo habitus e pela organização do estado no Norte de Minas (COSTA, João Batista de Almeida)

funcionários públicos responsáveis pelo funcionamento dos locomóveis ${ }^{11}$ onde a energia elétrica era produzida.

Já no século XX, em algumas cidades são instalados cinemas para o lazer das populações locais, sendo seus proprietários as famílias donas das fábricas de tecido vinculados aos operadores do maquinário cinematográfico. E, ainda, a presença de telefonia, ainda que precária, que propiciava a vinculação da fazenda com a residência urbana de seu proprietário ou de moradores das povoações entre si. Com o passar do tempo emerge em cada localidade uma companhia para gerenciar a telefonia local, com gestores, funcionários administrativos e operadores de telefones.

Ao mesmo tempo, Wells (1886) informa a existência de uma moeda distinta da imperial, instituída pelo Barão de Jequitaí, que circulava em seus domínios entre o rio das Velhas e o rio Jequitaí. Podemos dizer que há uma incipiente atividade bancária, que vinculava o instituidor aos utilizadores dessa moeda micro-regional.

Após o planejamento estratégico do progresso imperial a partir dos anos 1860 sob o comando de Pedro II, inicia-se a instalação de estrada de ferro acompanhando, ainda que distanciado, o rio São Francisco, e a concessão de ramais vinculando vilas distanciadas do rio a diversos lugares em suas margens, como a concessão adquirida pelo Tenente Coronel Cipriano de Medeiros Lima vinculando Montes Claros à Extrema, atual Ibiaí. Essa estrada começou a ser implantada articulando engenheiros ingleses e trabalhadores braçais e teve paralisada sua construção em decorrência de acontecimentos morais que desagradaram o concessionário que foi ao Rio de Janeiro e vendeu sua concessão para ingleses.

No planejamento imperial o vale do São Francisco constituir-se-ia como o lugar do progresso brasileiro e para tanto, era necessário implantar um sistema viário articulando ferrovias e hidrovias, quando os vapores do Mississipi são adquiridos e passam a navegar pelo rio da integração nacional. Entretanto, o planejamento imperial, alicerçado nas observações de viajantes estrangeiros, notadamente Burton (1977) e Wells (1886), ficou nos escritos de diversos técnicos como Halfeld (1860), Liais (1865),

\footnotetext{
11 Locomóvel é uma máquina a vapor automotora usada para movimentar cargas pesadas sobre estradas, para aragem de solo ou para fornecer energia em locais determinados. Um locomóvel tende a ser grande, robusto e de grande potência, sendo porém pesado, lento e de baixa manobrabilidade. Vide: https://pt.wikipedia.org/wiki/Locom\%C3\%B3vel acessado em 02/01/2019 às 13:45.
} 
Artigo |A sociedade de curral: desenvolvimento social pelas figurações sociais, pelo habitus e pela organização do estado no Norte de Minas (COSTA, João Batista de Almeida)

Sampaio (2002) dentre outros, porque não foi implementado devido ao golpe de Estado que pôs fim ao Império e instaurou a República. Esse planejamento foi obscurecido na historiografia brasileira escrita por paulistas.

Em fins do século XIX, quando do boom da borracha, principalmente nas chapadas da margem esquerda do rio São Francisco e na calha de formação do rio Pardo, homens dedicaram-se à coleta do látex de mangaba que propiciou ser a região a segunda maior produtora internacional de borracha, com o estabelecimento do comércio internacional do látex de mangaba.

Informações sobre essa atividade foram disponibilizadas por Pierson (1950) sobre a atividade nas chapadas da margem esquerda do rio São Francisco e Neves (2008) sobre a presença dos mangabeiros na calha de formação do rio Pardo. Esse extrativismo se constituiu como atividade complementar ao sistema produtivo das famílias sertanejas. Há interdependência das figurações que articulava os mangabeiros, sejam pessoas dedicadas exclusivamente ao extrativismo do látex de mangaba, os lavradores que tinham na atividade uma possibilidade de ampliação da atividade produtiva agrícola, pastoril e extrativista e os comerciantes locais que adquiriam a produção de cada localidade, bem como os comerciantes dos grandes centros para onde a borracha era comercializada.

Nesse mesmo período, podemos afirmar que a civilização chega ao sertão com a fixação dos religiosos da Ordem Premonstratense, conforme narrativa de Gaspar (s/d). Em seu estudo sobre a história do desenvolvimento Rist (1997) informa que na vigência do imperialismo, em virtude da leitura hierarquizante dos povos do mundo, quando a Europa se afirmou civilizada para expressar a consciência de si mesma, conforme discutido por Elias (1994), cabia a cada império buscar ampliar o seu progresso, tanto para a metrópole quanto para as colônias, quando seus administradores e missionários atuavam objetivando civilizacionar os povos hierarquicamente inferiores.

Nesse sentido, a atuação dos religiosos premonstratenses com a criação de colégios, santa casa de misericórdia, orfanatos, banda de música, jornais, teatros, congregações religiosas leigas, dentre outras coisas, espalhou pela região norte mineira os pilares da civilização moderna, ao mesmo tempo que ampliava a cristianização das populações locais. Esses civilizadores almejavam elevar o padrão de comportamento das gentes norte mineiras. 
Artigo |A sociedade de curral: desenvolvimento social pelas figurações sociais, pelo habitus e pela organização do estado no Norte de Minas (COSTA, João Batista de Almeida)

Em fins do séculoXIX é apresentado à Assembléia Legislativa de Minas Gerais um projeto de colonização da região da Jaíba, conforme Velloso (1901), em consonância com o planejamento nacional de incorporação de mão de obra européia com a estratégia da migração. A proposta de colonização norte mineira atraiu uma quantidade de famílias européias, notadamente italianas, mas não somente, que impedidas de se fixarem na área em decorrência da endemia de malária as afugentaram para as encostas e chapadas da serra do Espinhaço, dando origem a duas categorias étnicas norte mineiras, os geraizeiros que se localizaram notadamente nas proximidades dessa mesma serra em Rio Pardo de Minas e os caatingueiros, que eram partes das famílias geraizeiras que desceram a serra para as bordas do vale do rio Verde Grande em Riacho dos Machados, Porteirinha e Mato Verde.

Importante notar que a região da Jaíba, palavra tupi-guarani que em outras palavras informava a existência da referida endemia, foi assim denominada pelos membros da bandeira de Mathias Cardoso de Almeida que originalmente procurou ocupar o vale do rio Verde Grande, mas que dele se afastou devido à malária que causava a morte de membros dessa bandeira.

Ao mesmo tempo em que os migrantes europeus vieram para ocupar os postos de trabalho deixados vagos com o fim da escravidão, a elite nacional, também, buscava embranquecer a população brasileira fundamentada no prognóstico do Conde de Gobineau e de Louis Agassiz de que a sociedade brasileira não progrediria em decorrência da miscigenação entre as raças.

Em termos figuracionais, os geraizeiros dedicaram-se à produção agrícola e pastoril, com divisão sexual e geracional do trabalho no âmbito interno de cada família e, externamente, estabelecendo relações comerciais principalmente com a Vila de São José do Gorutuba e com a Vila de Rio Pardo de Minas. Após a descida de parte dos membros dessas famílias para a área de caatinga, que se especializaram principalmente na comercialização da produção dos gerais com outras localidades, notadamente as situadas nas margens do rio São Francisco, passaram a se dedicar principalmente à criação de gado bovino e eqüino e ao comércio de produtos agrícolas adquiridos dos geraizeiros das encostas e chapadas da serra do Espinhaço, conforme Costa e outros (2017). 
Artigo |A sociedade de curral: desenvolvimento social pelas figurações sociais, pelo habitus e pela organização do estado no Norte de Minas (COSTA, João Batista de Almeida)

Com a instauração da República, as terras devolutas originadas no processo de aquisição de terras em conformidade com a Lei da Terra de 1850 foram destinadas a cada um dos Estados Unidos do Brasil, com exceção das terras indígenas, das terras nas margens de rios interestaduais e no litoral brasileiro que permaneceram com a União. No caso de Minas Gerais, frente ao empobrecimento da sociedade mineradora com a decadência da exploração aurífera, engenheiros formados pela Escola de Minas em Ouro Preto passaram a realizar divisões de terra por todo o interior mineiro.

Conforme relato de Vianna (1956), engenheiro que se deslocou para a região norte mineira em 1910, membros das famílias "tradicionais" de Montes Claros, Coração de Jesus e Brasília foram instruídos como agrimensores e sob seu comando, neste período inicial, passaram a operar divisões de terras onde fossem contratados por fazendeiros.

Em dois estudos seminais, o conflito de terras de Cachoeirinha, conforme estudo de Santos (s/d) e a construção da exclusão, da discriminação e da evitação de Brejo dos Crioulos pela negra sociedade de São João da Ponte, estudo de Costa (1999), esses agrimensores desenvolveram a estratégia de intercalar entre as glebas das famílias negras situadas no vale do rio Verde Grande, as chamadas glebas de ausentes. Importante salientar que as famílias negras só puderam acompanhar a divisão em decorrência da intervenção de Padre Gangana na defesa de sua família que chamou Antônio Dó, rebelde primitivo que em luta contra fazendeiros em São Francisco, inicialmente, depois por toda a região, defendia as famílias das gentes miúdas contra a ganância dos fazendeiros.

Em Brejo dos Crioulos ele aprisionou o agrimensor e o genro do fazendeiro que abriu o processo de divisão de terras e depois de negociações ficou estabelecido que as famílias negras pagariam os serviços com a entrega de uma vaca parida. Assim, as famílias negras, quilombolas históricos que ocupavam o interior da mata no vale do rio Verde Grande, puderam permanecer nas terras ocupadas por seus antepassados. Figuracionalmente o processo de divisão de terras que tem início nos anos 1910 articulou agrimensores, fazendeiros, foiceiros, vaqueiros, sitiantes e posseiros em relações desiguais.

Ampliando a estruturação do Estado na sociedade norte mineira são instauradas diversas comarcas com seus fóruns e seus funcionários operadores do Direito, além de 
Artigo |A sociedade de curral: desenvolvimento social pelas figurações sociais, pelo habitus e pela organização do estado no Norte de Minas (COSTA, João Batista de Almeida)

um número inicial restrito de advogados que retiraram das Câmaras Municipais a legislação e o policiamento da vida cidadã. Ao mesmo tempo, destacamentos de policiais foram sendo implantados nas sedes das comarcas. A sociedade regional, figuracionalmente, se complexificava com a presença dos operadores do direito e operadores da ordem pública.

O governo federal deu continuidade ao planejamento do tráfego ferroviário pela região e estendeu a estrada de ferro até Pirapora em 1910, conforme estudos de Lessa (1993). Para que a linha férrea chegasse a essa cidade, foi implantada como ramal desde a cidade de Corinto. A via principal se estendeu até Montes Claros por interveniência de ministro nascido na região e foi inaugurada nessa cidade em 1926.

A Rede Ferroviária Federal S/A que vincularia a cidade do Rio de Janeiro à Salvador pelo interior dos estados fluminense, mineiro e baiano ficou paralisada até que, em decorrência da segunda guerra mundial e o afundamento de navios brasileiros, o governo federal deu continuidade à implantação da referida linha. Duas frentes de serviço foram instaladas, uma vinda do norte e outra subindo do sul até o encontro das duas frentes que se deu na cidade de Espinosa.

Nesse período, a mata da Jaíba começa a ser devastada com a derrubada de madeira de lei para fornecer dormentes necessários à implantação das linhas férreas e, ao mesmo tempo, centenas de homens negros fixados no interior da referida mata se deslocam para o trabalho braçal de implantação da estrada ferroviária. A presença dos mesmos se deve à endemia de malária que oportunizou a implantação de dois centros de combate à essa doença, os Serviço de Assistência Médica Domiciliare de Urgência SAMDUs, em Montes Claros e Monte Azul que eram operacionalizados por médicos e enfermeiros deslocados para essas cidades como funcionários da rede ferroviária.

Ser ponto de linha significou para Montes Claros o aparecimento de um sem número de casas de prostituição para atender a demanda daqueles que acorriam à cidade para comercialização de suas produções no mercado local ou para envio à Belo Horizonte para ser comercializada nas ruas da capital estadual e, ainda, para atender aos trabalhadores da estrada de ferro que se fixaram na cidade, bem como, às dezenas de migrantes vindos do Nordeste brasileiro, notadamente da Bahia, que passaram a residir na cidade. 
Artigo |A sociedade de curral: desenvolvimento social pelas figurações sociais, pelo habitus e pela organização do estado no Norte de Minas (COSTA, João Batista de Almeida)

O funcionamento da estrada de ferro viabilizou o deslocamento de funcionários especializados no maquinário ferroviário e em Montes Claros foi instalada uma oficina central para o atendimento das necessidades de cada composição férrea. E na principal cidade da região instalou-se um número considerável de famílias em uma área próxima à estação e à oficina, dando origem na cidade de um bairro quase integralmente vinculado aos ferroviários, que organizaram um clube social e um time de futebol com a mesma denominação da categoria. Cabe notar que já existiam outros times de futebol na cidade, um vinculado à elite local e outro vinculado às camadas médias da sociedade montesclarense. E, posteriormente, com a instalação de uma indústria de beneficiamento do algodão para fabricação de óleo de cozinha, um time de futebol foi organizado junto aos industriários.

A Sociedade de Curral norte mineira se complexificava, figuracionalmente, tanto no processo de implantação da estrada de ferro com a presença de engenheiros, trabalhadores braçais, comerciante de madeira que articulou um número considerável de trabalhadores para a derrubada da mata e, desta forma, descortinou dezenas de comunidades negras que viviam invisibilizadas no interior da mata do vale do rio Verde Grande. Também, de toda uma gama de trabalhadores necessários ao pleno funcionamento do tráfego ferroviário que conduzia para Belo Horizonte a produção agrícola e pastoril em seus vagões, e ainda, as gentes em trem específico para o transporte humano. O vínculo entre as cidades norte mineiras com as capitais baiana, por um lado, mineira e fluminense por outro, tornou-se mais dinâmico.

As sociedades locais norte mineiras, principalmente Montes Claros, passam por um processo de modernização de suas infra-estruturas urbanas com a implantação de pavimentação das ruas, energia elétrica, abastecimento de água, telefonia, clubes sociais e empresas de lazer e entretenimento. Amplia-se o processo civilizador, via refinamento do comportamento da população por meio da implantação de conservatório de artes. Ao mesmo tempo em que as colunas sociais nos jornais locais enunciaram continuamente que a alta elite deveria afastar de seus círculos de convívio festivos, aqueles que passaram a ser denominados como penetras, notadamente a classe média $\mathrm{E}$, ao mesmo tempo, manifestavam a necessidade de homens mal vestidos e brutos da high society comportassem como suas mulheres, bem vestidas e educadas, para maior deleite de todos nos acontecimentos sociais. 
Artigo |A sociedade de curral: desenvolvimento social pelas figurações sociais, pelo habitus e pela organização do estado no Norte de Minas (COSTA, João Batista de Almeida)

Assim, as elites locais ampliam o processo de ruptura das relações de sociabilidade entre todos para fechamento em grupos tradicionais e empreendedores. E no período, entretanto, o principal evento de mostra da produção regional no Parque de Exposições permanecia aberto a todas as gentes que ao local se dirigiam durante os dias em que o mesmo acontecia.

Os clubes sociais demarcam as divisões entre a população em geral e a elite de cada localidade. Descendentes dos mineiros, que no século anterior migraram para o Norte de Minas, deram instalação às vilas pela emergência das câmaras municipais que eram a base primeira do ordenamento administrativo do Estado. Em cada cidade o clube social reunia as famílias da elite em seus festejos ou em seus cotidianos, os homens de bem participavam de jogatinas, dado que era neste espaço que os jogos aconteciam. $\mathrm{E}$ a massa da população de cada localidade via-se, cada vez mais, distanciada daqueles que ainda se mantinham como parceiros em suas fazendas e nas confrontações políticas pelo poder local.

Terminada a segunda guerra mundial, os Estados Unidos da América assume a hegemonia entre os países do mundo e instaura uma nova ordem mundial desde o discurso de posse de Truman em 1948, dando partida ao fim dos impérios coloniais e dividindo os povos entre desenvolvidos e subdesenvolvidos, como discutido por Rist (1997).

Entre as estratégias estadunidenses de desenvolvimento, espalhou-se 0 evangelismo, principalmente na América Latina por meio da Congregação Cristã e Assembléia de Deus. Ao mesmo tempo propugnou pela emergência de sociedades e empresas de classe, dando origem às sociedades rurais e às cooperativas rurais que na região norte mineira propiciou a criação dessas duas formas de organização das categorias rurais patronais. Embora a cooperativa que se instalou em Montes Claros tenha tido em seu inícioa presença de membros das camadas rurais médias e pequenas.

A emergência da sociedade rural e da cooperativa agropecuária propiciou uma mudança significativa no comportamento da elite agrária norte mineira que localmente se conflitava politicamente em facções que dividia, pelo mandonismo, a vida de cada municipalidade. Cada facção arregimentava a gente miúda por meio de relações familiares e de compadrio para a formação da parentela de cada chefe de facção, em 
Artigo |A sociedade de curral: desenvolvimento social pelas figurações sociais, pelo habitus e pela organização do estado no Norte de Minas (COSTA, João Batista de Almeida)

sua maioria vinculados à Guarda Nacional, nesta perspectiva, vide Queiróz (1976), em seu estudo sobre o mandonismo local.

As relações horizontalizadas, dentro de cada parentela no escopo do faccionalismo, começam a ser desmanteladas em favor da verticalização entre as categorias sociais que formavam a configuração social norte mineira, até esse período.

A nova ordem mundial requeria a solidariedade inter-classe articulada pelas sociedades e empresas patronais, dando origem, no Norte de Minas à ruptura interclasses que foi extremamente eficaz no processo de expropriação territorial a partir da incorporação da área norte mineira, integrante do Polígono das Secas, à atuação da Superintendência de Desenvolvimento do Nordeste e a disponibilidade de investimentos para modernização das fazendas como disposto no Estatuto da Terra de 1964.

A chegada da SUDENE à região norte mineira propicia a expansão das relações capitalistas que promoveu mudanças profundas na forma de vinculação com a terra, na medida em que propiciou a privatização das glebas. Ocorreu o consequente cercamento, a introdução de novas práticas de cultivo e de criação de gado, após o desmatamento da área e o reflorestamento das chapadas com eucalipto e pinus, para subsidiar o pólo siderúrgico em implantação na área central mineira.

Com essas mudanças, todo o sistema de apossamento atualizado, desde o passado pelas gentes miúdas, entrou em colapso. Houve o impedimento da atualização de diversas práticas produtivas, da solta do gado na larga situada no interior da mata, do cercamento apenas da área de cultivo com a introdução de cerca de arame farpado e o empastamento com capins exóticos para gado de raças diferenciadas.

Na interpretação de um quilombola de Matias Cardoso, a partir desse tempo os pequenos cercaram a solta do gado, deram fim ao ofício do vaqueiro que campeava para si e para os parentes. E, por fim, as terras devolutas, até então utilizadas em comum por grandes fazendeiros e moradores, para a criação do gado na solta são privatizadas, cercadas ou reflorestadas.

A expansão das relações capitalistas de produção na sociedade norte mineira ocorre, conforme subsídios de Augusto (1988) num concerto de estratégias de intervenção do Estado para modernizar a economia regional. A instalação inicial de instituições estatais como o Departamento Nacional de Obras Contra a Seca, a 
Artigo |A sociedade de curral: desenvolvimento social pelas figurações sociais, pelo habitus e pela organização do estado no Norte de Minas (COSTA, João Batista de Almeida)

Companhia de Desenvolvimento do Vale do São Francisco e a Superintendência de Desenvolvimento do Nordeste propiciaram por um lado a implantação de infraestrutura necessária à instalação de empresas capitalistas com capital local ou vindos de outras regiões do país, em busca dos financiamentos a juros subsidiados e dos incentivos fiscais e financeiros, por meio do qual tornou possível a reprodução do capital na região. E, por outro lado, em decorrência dos investimentos e financiamentos disponibilizados um processo violento de expropriação territorial dos sitiantes, posseiros e pequenos proprietários, forçando o êxodo rural e o inchamento das cidades e, conseqüente, concentração fundiária, a chamada modernização conservadora do campo.

$\mathrm{E}$, ainda, por uma terceira via, a implementação de projetos voltados para as camadas inferiores da população rural administrados por empresas estatais ou organismos de Estado que visavama melhoria das condições de produção dos pequenos produtores rurais. E, também, projetos voltados para grandes empresários, notadamente a implantação de grandes áreas irrigadas no cultivo de produtos para atendimento do mercado nacional e, mesmo, internacional.

No presente, conforme Costa e Araújo (2013), essas relações são atualizadas num contexto de maior restrição, quando as fazendas, espaços de produção agrícola com investimento de capital mediante financiamentos e subsídios governamentais, buscam manter e estender o domínio sobre amplas áreas para a criação de gado. Há para a gente miúda, o cerceamento das práticas produtivas agrícolas que preponderaram no passado, como a abertura de roças novas e descanso de antigas áreas de cultivos forçando a adoção da prática no mesmo local de cultivo de anos anteriores. Mesmo neste contexto de restrições administrativas, ambientais e policialescas, aqueles que persistem no lugar e não abrem mão de decidir o que incorporar "do novo" e como reproduzir saberes e fazeres transmitidos entre gerações.

A vivência religiosa, des de a emergência da Sociedade de Curral, em meados do Século XVII, foi organizada em uma figuração que articulou pastores católicos e seus rebanhos. Nas povoações sede de freguesias/paróquias os sacerdotes atendiam diuturnamente aos fiéis, enquanto nas povoações rurais somente nas desobrigas anuais. A partir disto, emerge ao longo do processo a figuração entre um catolicismo romano organizado pela hierarquia eclesial com as gentes, na forma do padroado que existiuaté 
Artigo |A sociedade de curral: desenvolvimento social pelas figurações sociais, pelo habitus e pela organização do estado no Norte de Minas (COSTA, João Batista de Almeida)

a laicização com a República ao Estado. E um catolicismo popular em que os leigos locais ocupam o papel central na vivência religiosa de cada coletividade que dá primazia ao devocional em que os sacerdotes são sempre especialistas pagos para executarem atividades sacramentais, notadamente batismos e casamentos. As figurações que articulam a vida religiosa norte mineira nesse escopo vincularam por um lado, sacerdotes e fiéis e por outro lado, agentes locais do sagrado e os membros de cada localidade.

A partir da década de 1910, outras vivências religiosas emergem na vida dos norte mineiros, como o protestantismo com a instalação da Primeira Igreja Batista e do primeiro Terreiro de Umbanda, ambos em Montes Claros. E nos anos 1950 a chegada do evangelismo com a disseminação de fiéis vinculados às igrejas Congregação Cristã do Brasil e Assembléia de Deus, sendo que em Santa Rosa de Lima, houve nos anos 1960 uma guerra religiosa, como discutido por Lopes (2006), bem como a emergência do Candomblé. As figurações que organizam as práticas religiosas articulamo líder religioso com os fiéis na perspectiva cristã e nas duas religiões de matriz africana, a entidade, o zelador (pai ou mãe de santo), diversos iniciados com funções diversas e a clientela ${ }^{12}$.

As figurações que organizam a religiosidade na Sociedade de Curral se complexificaram à medida que o processo civilizador brasileiro se desenvolveu desde seu início, com a implantação do catolicismo romano e a proibição das religiosidades indígenas. Com o transcorrer do tempo, as populações rurais passam a organizar suas coletividades em torno da devoção a santos, como discutido por Queiróz (1976 b), tendo como agentes do sagrado os ternos de folia, ternos de congado e ternos de terço. Após a instauração da República e a laicização do Estado, emergiram outras possibilidades figuracionais com as religiosidades protestantes, evangélicas e de matriz africana, que articulam, no caso cristão, o especialista e os fiéis e no caso da Umbanda e Candomblé, as entidades, o pai/mãe de santo, diversos especialistas e os fieis iniciados ou não.

E, antes de encerrar a argumentação baseado na teoria de processo civilizador de Elias (1994), desenvolvo uma possibilidade de leitura das figurações que organizam a Sociedade de Curral ao abordá-la na perspectiva de Geertz (1989). Para este autor as idéias são significados veiculados através de símbolos, que intersubjetivos são públicos

\footnotetext{
12 Os estudos sobre as religiões de matriz africana foram desenvolvidos por Marques (2011).
} 
e, assim, textos para serem lidos, dado o real ser tão imaginado quanto o imaginário, como dito em Negara (GEERTZ, 1991).

Nos estudos que têm sido feitos por pesquisadores norte mineiros nas comunidades que compõem a Sociedade de Curral em que se encontram inseridos é recorrente a leitura nativa pela oposição forte x fraco. Em suas interpretações da vida local, os comunitários das localidades interioranas focalizam esta oposição prioritariamente nos conflitos por terras, notadamente nos anos 1960 em diante. Nesse período, profissionais liberais procurando se afazendar e fazendeiros chegaram secundados por bandos de jagunços armados até os dentes para tomar as terras. $\mathrm{E}$ tomaram-nas com diversos artifícios, todos eles cercados de extrema violência. $\mathrm{Na}$ narrativa abaixo, um lavrador evidencia a correlação de forças entre os fortes x os fracos:

Fraco é que nem cachorro na boca da onça. O fazendeiro. Eu tenho condição de brigar com um fazendeiro? Eu vou brigar com ele! Eu vou latir a ele e ele me comer. Éigual a onça. Igual a onça. Tem mais dinheiro. O que eu vou fazer com ele? Não posso fazer nada. Se por acaso, ele é fazendeiro, eleé tataú. É o caso desse homem, tataú. É como a gente fala. Onça brigar com cachorro, este vai comido. Onça passa por cima dele (COSTA, 1999, p. 58, grifos no original).

O tempo da expropriação das terras passou, as fazendas estão estabelecidas e nelas os fracos podem ofertar sua mão-de-obra para serviços permanentes ou temporários.

Nos tempos atuais, outra significação é enunciada recorrentemente, a de que as gentes miúdas são fracas frente aos empresários do agronegócio, aos comerciantes das cidades e aos políticos de uma forma geral. A relação social entre dois grupos humanos é simbolicamente construída por imagens diferenciadas atribuídas mutuamente. Entre os dois grupos foi estabelecida uma relação hierárquica, em que o poder e o status criaram e criam tensões entre eles. O que quero enfatizar é o conteúdo do poder hierárquico entre os dois grupos.

As gentes miúdas norte mineiras foram subjugados pelo poder daqueles que se afazendaram utilizando de extremada violência. A população subjugada se vê como fraca em oposição a quem as dominaram, os fortes. Nessas duas categorias, que 
Artigo |A sociedade de curral: desenvolvimento social pelas figurações sociais, pelo habitus e pela organização do estado no Norte de Minas (COSTA, João Batista de Almeida)

propiciam aos subalternos lerem a realidade social da Sociedade de Curral, confrontamse duas sociedades diferenciadas: aquela baseada na horizontalidade das relações com sociabilidades que articulavam gentes em posições diferenciadas como uma parentela e a outra que a partir dos anos 1960 espalhou suas raízes por toda a região transformando sua característica fundamental de uma vida circundada, em torno do curral, para contribuir para que o sertão pudesse ser amansado, adestrado e domesticado e para que os chamados vazios nacionais fossem enredados por suas tramas sociais enfeixadas no Centro-Sul, perspectiva enunciada por Oliveira Filho (2018).

Na tensão entre a Sociedade de Curral que vai sendo desarticulada pela emergência da sociedade cosmopolita, que não irei tratar aqui, há outra categoria interpretativa importante e que remete, exatamente, aos fundamentos da Sociedade de Curral: curraleiro. Essa é a designação comum dada a tudo que possa estar no espaço de um curral: diz-se do gado que fica em curral. Diz-se de uma raça bovina ${ }^{13}$.

Entretanto, na sociedade norte mineira o significado desliza para outros sentidos. Em sua autobiografia Darcy Ribeiro (1988) relatou o desejo recorrente dos norte mineiros de criação de uma unidade política própria e propõe o etnômio, curraleiro para essa gente. Ao recobrir todas as gentes norte mineiras, o autor ilumina a possibilidade da leitura da sociedade onde nasceu, como a Sociedade de Curral.

Mas esta é uma leitura intelectualizada que não é compartilhada pela elite local que se utiliza dessa categoria de entendimento do mundo para se referir às gentes miúdas. Essa categoria designa pessoas consideradas pobres e é comum se ouvir: casei com uma curraleira, ou um curraleiro. Essa afirmação informa que entre os noivos há um casamento entre pessoas de posições econômicas diferenciadas, como se fosse um casamento para cima ou para baixo, como discutido em Bourdieu (1962) nas estratégias do campesinato francês.

Mas há muitas outras práticas de informar a existência de coisas curraleiras, a cachaça fabricada artesanalmente por agricultores familiares e que não passa pela sacramentação dos organismos econômicos e tributários do estado. Se a denominação emerge para distinguí-la do destilado fabricado em larga escala cujo resultado, para os

\footnotetext{
${ }^{13} \mathrm{https}$ ://www.dicio.com.br/curraleiro/ acessado em 01/02/2019 às 17:49 hs.
} 
Artigo |A sociedade de curral: desenvolvimento social pelas figurações sociais, pelo habitus e pela organização do estado no Norte de Minas (COSTA, João Batista de Almeida)

norte mineiros, há perda de qualidade. Sendo assim, cachaça curraleira é aquela boa para se degustar.

Nesse mesmo sentido, há o queijo curraleiro, o doce de leite curraleiro, dentre outras tantas possibilidades de nomeação.

Na oposição forte $x$ fraco, tais denominações informam relações de dominação e subordinação. Na utilização da categoria de entendimento de mundo das coisas norte mineiras como curraleiras, pode-se fazer a leitura da pejorativação das coisas organizadas em torno do criatório de gado de corte e de enunciação afirmativa da dominação nas relações sociais e de sociabilidade. E, lida na perspectiva da teoria da subalternidade, na voz das gentes miúdas, as coisas curraleiras, sejam pessoas, gado rústico, comidas e bebidas, são ditas a partir de um lugar enunciatório de onde se pode ver a interioridade da Sociedade de Curral, a partir de fora, como discutido em Bhabha (1998: 39). E a categoria curraleiro constitui-se a linguagem da afirmação da diferenciação a partir da emergência e consolidação da sociedade cosmpolita nos anos 1960.

\section{À guisa de conclusão: o processo civilizador da sociedade curraleira}

A argumentação construída condensa e interconecta relatos históricos sobre a formação social do Norte de Minas que se encontram dispersos em várias obras/autores, o que propicia uma boa fundamentação para a elaboração final das configurações da sociedade de curral, explorando as várias significações do sujeito curraleiro. Ao desconstruir a linguagem da dominação que constrói historicidades, pude trazer à luz a leitura que venho construindo em meu percurso intelectual e que tem contribuído para desconstruções provocadas por minha interpretação que se fundamenta na perspectiva do Bhabha (1998), tanto quanto na do Elias (1997), pois ambos orientam toda a minha reflexão.

No percurso construído na argumentação, li de forma ensaística a sociedade norte mineira como uma formação social em que os indivíduos estão ligados entre si de modo específico de dependências recíprocas e cuja reprodução supõe um equilíbrio de tensões, como desenvolvido por Elias (1997). E articuladas por essas dependências recíprocas, procurei ler o desenvolvimento social desta sociedade de curral focalizando 
Artigo |A sociedade de curral: desenvolvimento social pelas figurações sociais, pelo habitus e pela organização do estado no Norte de Minas (COSTA, João Batista de Almeida)

os habitus que organizam as práticas das individualidades e a organização do Estado que distanciado por um longo período, denominado isolamento, aos poucos vai se fazendo presente até impor transformações profundas no processo civilizador dessa sociedade. E propiciar a emergência de outras figurações que alça a sociedade de curral para o patamar de uma sociedade cosmopolita.

As individualidades interconectadas ao longo do processo civilizador da Sociedade de Curral não se constituem seres atomizados, mas categorias sociais que se relacionam na organização social da gente norte mineira em sua historicidade.

$\mathrm{Na}$ anterioridade dos anos 1660 indígenas e quilombolas articulavam-se intra e inter grupos sociais por princípios de reciprocidade e solidariedade, organizando uma sociedade multicultural e multiétnica, não havendo centralização de poder político e nem uma autoridade central que os submetesse a sua dominação. Entretanto, essas mesmas gentes dispersas pelo território ainda não desbravado pelo colonizador português e seus colonos associaram-se, para lutar contra a interiorização das frentes colonizadoras voltadas, naquele período, para a produção açucareira.

A população branca, com seus escravos indígenas e afro-brasileira, que se fixou às margens dos rios Verde Grande, primeiramente, e do São Francisco após concretizar o objetivo de aprisionamento de indígenas e extermínio de quilombolas, espalhou-se em diversos pontos da área implantando fazendas de criação de gado e deu fundação à Sociedade de Curral com uma figuração bastante simplificada, senhores vinculados entre si e escravos submetidos a cada um dos fazendeiros que ampliaram os Currais do São Francisco, nessa região sertaneja. Com a consolidação da organização social implantada, novas figurações emergem nas individualidades de comerciantes, educadores, religiosos e incipiente funcionalismo para dar fundação à Vila de Nossa Senhora da Conceição de Morrinhos, que não se verificou.

Após as tentativas da coroa portuguesa de isolar a incipiente economia privada que abastecia a região das minas generalizadas e submetê-la ao sistema colonial centralizado que foi implantado para viabilizar que o ouro extraído de catas, lavras e minas fosse prioritariamente para Portugal, a Sociedade de Curral processa a complexificação das figurações sociais ao se conectar com outras áreas da Colônia Brasil. Como o comércio com a região mineradora no entorno do pico Itacolomi minimizou os ganhos, a produção norte mineira expande-se para Goiás e Mato Grosso em meados do 
Artigo |A sociedade de curral: desenvolvimento social pelas figurações sociais, pelo habitus e pela organização do estado no Norte de Minas (COSTA, João Batista de Almeida)

Século XVIII. Ao mesmo tempo em que novas povoações e novas atividades produtivas, não alicerçadas prioritariamente na produção agropastoril, propicia a emergência de outras individualidades como garimpeiros notadamente em Grão Mogol e Jequitaí.

Em decorrência da Guerra de Secessãonos Estados Unidos que cuja produção de algodão teve sua exportação minimizada, dados os vínculos entre a sociedade norte mineira e a sociedade do Baixo São Francisco, essa matéria prima supriu a demanda de algodão da produção têxtil inglesa. E, logo em seguida, com outros mercados internacionais, quando do boom da borracha com a coleta de látex de mangaba, que propiciou tornar-se o segundo produtor mundial desse produto.

Decorre da complexificação da produção norte mineira a acumulação de capital, denominada de primitiva por encontrar-se fora do sistema de produção capitalista, propiciou que, na renovação tecnológica da indústria têxtil inglesa, a transferência de diversas fábricas de tecido, muitas das quais não chegaram a funcionar pela ausência de mercado, da Inglaterra para o Norte de Minas.

Nessa conjuntura a Sociedade de Curral, ainda que sua economia ampliasse as atividades produtivas, ela permanecia alicerçada prioritariamente no criatório de gado de corte e na produção agrícola para suprir sua própria demanda e a demanda do mercado interno brasileiro. Essa dualidade de abastecimento se deve às características distintas de produtores interessados em relações comerciais mais amplas e daqueles voltados para a reprodução das gentes miúdas espalhadas no território regional. Como evidenciado nos relatos de viajantes europeus ou de missionários que se estabeleceram no Sertão do São Francisco, a solidariedade intra social sustentou, como disse Burton (1977) e Gaspar (s/d) uma sociedade igualitária, na teoria e na prática. Essa característica regional começa a colapsar-se em meados dos anos 1940 com a instituição das sociedades rurais que aglutinaram em torno de si grupos, até então, faccionalizados que no processo de modernização conservadora da economia nacional expropriaram as gentes miúdas com as quais seus membros conviveram e alicerçaram seus mandos locais.

E desde a chegada dos missionários europeus em fins do Século XIX, o habitus da gente curraleira processa mudanças civilizacionais de comportamento transferidos da Europa em sua constituição como Ocidente, conforme discutido por Elias (1994), para se colocar como superior frente às centenas de sociedades existentes no mundo. E, aos 
Artigo |A sociedade de curral: desenvolvimento social pelas figurações sociais, pelo habitus e pela organização do estado no Norte de Minas (COSTA, João Batista de Almeida)

poucos ocorre uma ruptura na sociabilidade das gentes norte mineiras que aos poucos encastela a chamada high society em pequenos grupos em cada cidade e a exclusão de amplos setores das classes médias que passam a ser considerados penetras nos eventos dos grupos que passaram a se chamar de elite. E a grande maioria da população, a chamada plebe, se vê ainda mais distanciada de todos, passando a sofrer discriminações, exclusões e evitações em suas rotinas cotidianas, em seus empregos domésticos ou nas fazendas de criação de gado.

Co-temporalmente a este processo, o Estado, até então distanciado da Sociedade de Curral, implanta e consolida sua organização e submete as gentes curraleiras ao seu domínio. Ainda que tenham ocorridos diversos conflitos, aqui não narrados, entre os órgãos governamentais e, principalmente, a elite regional que diuturnamente buscava a criação de uma unidade federativa no espaço norte mineiro. Não sendo possível na geopolítica nacional, imbrica-se com a elite mineira e permanecer com seu mando local e regional consolidado, como sói ser, nas transformações econômicas e sociais que se instauraram e dão fundamentação à Sociedade Cosmopolita desde os anos 1960.

Emerge, então, como evidenciado, nas categorias forte $\mathrm{x}$ fraco e curraleiro, configurações cada vez mais opostas, com projetos de sociedade distintos, tendo uma como objetivo primordial o lucro e a riqueza e a outra, organizada em comunidades tradicionais, lutando pela garantia e preservação de seus modos diferenciados de coexistência humana em interdependência com suas ecologias.

\section{Bibliografia}

ABREU, Capistrano - Capítulos da História Colonial (1500-1800). 7 ed. São Paulo: Publifolha, 2000. Grandes Nomes do Pensamento Brasileiro.

AMBRÓSıO, Manoel. Brasil interior: palestras populares, folk-lore das margens do S. Francisco. 1a. Edição. São Paulo: Nelson Benjamin, 1934, V. 1.

AMBRÓsıO, Manoel. Antonio Dó: o bandoleiro das barrancas. Petrópolis: Vespertino, 1976.

ANASTASIA, Carla Maria Junho - A Sedição de 1736: Estudo Comparativo entre a Zona Dinâmica da Mineração e a Zona Marginal do Sertão Agro-Pastoril do São Francisco. Belo Horizonte, 1983 (Mestrado em História) - Universidade Federal de Minas Gerais. 
ANTONIL, André João - Cultura e Opulência do Brasil. Belo Horizonte: Itatiaia; São Paulo: EDUSP, 1997.

ARAÚJO, Elisa Cotta de. Nas margens do São Francisco: sociodinâmicas ambientais, expropriação territorial e afirmação étnica do Quilombo da Lapinha e dos Vazanteiros de Pau de Légua. Montes Claros, 2009 (Mestrado em Desenvolvimento Social) - Universidade Estadual de Montes Claros.

AUGUSTO, Rosely Carlos. A intervenção do Estado na região Norte de Minas Gerais. Subsídios para discussão. Montes Claros: CPT, 1988 (mimeo).

BALAIO, João. Você sabe o que aconteceu em Montes Claros dia 13 de agosto do ano passado?. São Paulo: Símbolo, 1978.

BARREIROS, Eduardo Canabrava. Episódios da Guerra dos Emboabas e sua geografia. Belo Horizonte: Itaitiaia. São Paulo: EdUSP, 1984. Reconquista do Brasil, v. 83.

BERNARDEZ, Manuel - O Gigante Deitado. Notas e Actos de doze annos de vida no Brasil. Rio de Janeiro: Leite Ribeiro: $s / d, 2$ volumes.

BHABHA, Homi K. O Local da Cultura. Belo Horizonte: Editora da UFMG, 1998.

BOURDIEU, Pierre. Célibat et condition paysanne. Em Études rurales, pp. 32-135, 1962.

BRAZ, Brasiliano - São Francisco nos Caminhos da História. São Francisco: Lemi, 1977.

BURTON, Richard - Viagem de Canoa de Sabará ao Oceano. Belo Horizonte: Itatiaia; São Paulo: EDUSP, 1977. Reconquista do Brasil, 37.

CARDOSO, Vicente Licínio. À margem da história do Brasil. São Paulo: Nacional, 1979. Brasiliana, v. 13.

CARVALHO, José Jorge (Org.) - O quilombo do Rio das Rãs. Histórias, tradições, lutas. Salvador: EdUFBA. 1996.

CARVALHO FRANCO, Francisco de Assis - Bandeiras e Bandeirantes de São Paulo. São Paulo: Editora Nacional, 1940. Brasiliana, Vol. 181.

COSTA, João Batista de Almeida. A cultura sertaneja: a conjugação de lógicas diferenciadas. Em Santos, G. R. (Org) Trabalho, cultura e sociedade no Norte/Nordeste de Minas. Considerações a partir das Ciências Sociais. Montes Claros: Best Comunicação e Marketing, 1997, pp. 77-97.

COSTA, João Batista de Almeida. Da fartura no tempo dos crioulos à penúria no tempo dos morenos. Identidade através de rito em Brejo dos Crioulos (MG). Brasília, 1999 (Mestrado em Antropologia Social) - Universidade de Brasília.

COSTA, João Batista de Almeida Mineiros e Baianeiros: a configuração do englobamento, da exclusão e do entre-lugar em Minas Gerais. 1. ed. Montes Claros: Editora da Unimontes, 2017.

COSTA, J. B. de A., DAYRELL, C. A., FERREIRA, A. C. e LUZ, A. Grande Sertão: Veredas e seus ecossistemas. Em Revista Desenvolvimento Social, v. 1, n.1, p. 63- 78, 2008. 
COSTA, J. B. de A. e ARAÚJO, E. C. de. Relatório antropológico de caracterização histórica, econômica, ambiental e sócio-cultural da comunidade remanescente do Quilombo da Lapinha - Matias Cardoso (MG). Montes Claros: Unimontes; Belo Horizonte: INCRA, 2013 (mimeo).

COSTA, J. B. de A., DAYRELL, C. A., MARTINS, D., LEAL, G. F. e DAYRELL, L. Ser geraizeiro é atualmente lutar pela volta da água: Relatório Antropológico de caracterização de identidade étnica e de territorialidade da Comunidade de Moreira Rio Pardo de Minas. Rio Pardo de Minas: STR; Montes Claros: CAA / Norte de Minas; Brasília: Embrapa / Projeto BemDiverso, 2017 (mimeo).

COSTA SILVA, René Marc. Por onde o Povo Anda... A Construção da Identidade Quilombola dos Negros de Rio das Rãs. Brasília, 1998 (Doutorado em História) Universidade de Brasília.

ELIAS, Norbert. O processo civilizador: uma história dos costumes. Rio de Janeiro: Zahar, 1994.

. Os alemães: a luta pelo poder e a evolução do habitus nos séculos XIX e XX. Rio de Janeiro: Zahar, 1997.

ELIAS, N. e SCOTSON, J.L. Estabelecidos e outsiders: sociologia das relações de poder a partir de uma pequena comunidade. Rio de Janeiro: Zahar, 2000.

ESTEVES, Manoel. Grão Mogol. Rio de Janeiro: São José, 1961.

GASPAR, Maurice M. No sertão de Minas: o apostolado dos Premonstratenses da Abadia du Parc. Parc-Les-Nouvain, s/d (mimeo).

GEERTZ, Clifford. A interpretação das culturas. Rio de Janeiro: Guanabara, 1989.

GEERTZ, Cliffor. Negara: O estado teatro no século XIX. Lisboa: Difel; Rio de Janeiro: Bertrand Brasil, 1991. Memória e Sociedade.

GOMES, Flávio dos Santos - "Quilombos do Rio de Janeiro no Século XIX. In REIS, J.J e GOMES, F.S (org) - Liberdade por um fio. História dos quilombos no Brasil. São Paulo: Companhia das Letras, 1996, pp. 263-290.

HALFELD, Henrique Guilherme Fernando. Atlas e relatório concernente à exploração do rio de São Francisco da cachoeira de Pirapora até ao Oceano Atlântico. Rio de Janeiro: Eduardo Rensburg, 1860.

LASMAR, Jorge e VASQUES, Terezinha. Grão Mogol. Contagem: Líthera Maciel, 2005.

LESSA, Simone Narciso. Trem de Ferro: Do Cosmopolitismo ao sertão. Campinas, 1993 ((Mestrado em História) - Universidade de Campinas.

LIAIS, Emmanuel. Hydrographie du haut San-Francisco et du Rio das Velhas : ou, Résultats au point de vue hydrographique d'un voyage effectué dans la province de Minas-Geraes. Paris: Garnier; Rio de Janeiro: Garnier, 1865.

LINS, Wilson. O Médio São Francisco: Uma sociedade de pastores e guerreiros. Ensaio. 2a edição. Salvador: Livraria Progresso, 1960.

LOPES, Camilo Antônio da Silva. A Festa de Santa Rosa de Lima: Territorializações, religiosidade, clivagens sociais e coesão social no simbolismo ritual. 
Artigo |A sociedade de curral: desenvolvimento social pelas figurações sociais, pelo habitus e pela organização do estado no Norte de Minas (COSTA, João Batista de Almeida)

Montes Claros, 2006 (Monografia em Ciências Sociais) - Universidade Estadual de Montes Claros.

MATA-MACHADO, Bernardo Novais da. História do Sertão Noroeste de Minas Gerais (1690-1930). Belo Horizonte: Imprensa Oficial. 1991.

MARQUES, Angela Cristina Borges. Umbanda Sertaneja. Cultura e Religiosidade no Sertão Norte Mineiro. 01. ed. Montes Claros: Unimontes, 2011.

MAWE, John. Viagens ao interior do Brasil. Belo Horizonte: Itatiaia; São Paulo: EdUSP, 1978. Reconquista do Brasil, v. 33.

MELATTI, Júlio César. Índios do Brasil. 7ạ. Edição. São Paulo, Hucitec; Brasília: Editora da UnB, 1997.

NEVES, Antonino da Silva. Chorografia do Município de Boa Vista do Tremendal. Estado de Minas Gerais. Em Revista do Arquivo Público Mineiro, Anno XIII, pp. 219-239, 1908.

Corografia do Município de Rio Pardo. FAGUNDES, G. e Martins, N. (orgs). Montes Claros: Vereda Viva, 2008.

OLIVEIRA, Moisés Dias de. Autodefinição identitária e territorial entre os geraizeiros do Norte de Minas Gerais: o caso da comunidade de Sobrado. Brasília: UnB, 2017. Dissertação de Mestrado.

OLIVEIRA FILHO, Otaviano. Sertão e sertanejos: antinomias narradas entre o pensado no Brasil e o vivido no Norte de Minas Gerais. São Paulo, 2018 (Doutorado em Ciências Sociais) - Pontifícia Universidade Católica de São Paulo.

PAES, Pedro Taques de Almeida. Nobiliarquia Paulistana, História e Genealógica. 5 ed. Belo Horizonte: Itatiaia; São Paulo: EDUSP, 1980, 2 volumes.

. Notícias das Minas de São Paulo e dos Sertões da mesma Capitania. Belo Horizonte: Itatiaia; São Paulo: EDUSP, 1980 a. Reconquista do Brasil, Nova Série, Volume 27.

PAULA, Hermes de. Montes Claros, sua História, sua Gente e seus Costumes. 1ạ. Ed. Rio de Janeiro: Serviço Gráfico do IBGE, 1957.

PIERSON, Donald - O Homem do Vale do São Francisco. Rio de Janeiro: Minter/SUVALE, 1972, 3 volumes.

PIRES, Simeão Ribeiro. Raízes de Minas. Montes Claros: Minas Gráfica, 1979.

Cuatiara, 2001. Serra Geral: Diamantes, Garimpeiros \& Escravos. Belo Horizonte:

PRADO JÚNIOR, Caio. Formação do Brasil Contemporâneo: Colonia. Belo Horizonte: Itatiaia; São Paulo: Publifolha, 2000. 408. Grandes nomes do Pensamento Brasileiro.

PUNTONI, Pedro. A Guerra dos Bárbaros. Povos Indígenas e Colonização no Sertão. São Paulo: Hucitec, 2002.

QUEIRÓZ, Maria Isaura Pereira de. Mandonismo local na vida política brasileira e outros ensaios. São Paulo: Alfa-Ômega, 1976. 
. O campesinato brasileiro: ensaios sobre civilização e grupos rústicos no

Brasil. Petrópolis: Vozes, 1976 b.

RAMOS, Alcida Rita. Hierarquia e Simbiose: Relações Intertribais no Brasil. São Paulo: Hucitec, 1980.

. Sociedades indígenas. 3ạ. Edição. São Paulo: Ática, 1994. Série Princípios.

RIBEIRO, A. E. e Outros. A pequena produção rural na região de Montes Claros. Montes Claros: CTA, 1987 (mimeo).

RIBEIRO, Darcy. Migo. Rio de Janeiro: Guanabara, 1988.

RIST, Gilbert. The History of Development:The history of development: from western origins to global faith. London: ZED Books, 1997.

ROCHA, Geraldo. O rio São Francisco: fator precípuo da existência do Brasil. 3a . Edição. São Paulo: Nacional; Brasília: CODEVASF, 1983.

RICARDO, Cassiano. Pequeno Ensaio de Bandeirologia. Rio de Janeiro: Imprens a Nacional, 1956, Serviço de Documentação do Ministério da Educação e Cultura

SAMPAIO. Teodoro. O rio São Francisco e a chapada Diamantina. São Paulo: Cia das Letras, 2002.

SAINT-HILAIRE, Auguste - Viagem pelas Províncias do Rio de Janeiro e Minas Gerais. Belo Horizonte: Itatiaia; São Paulo: EDUSP, 1975.

SANTOS, Ana Flávia Moreira. Do terreno dos caboclos do Sr. São João à Terra Indígena Xariabá: as circunstâncias da formação de um povo. Um estudo sobre a construção social de fronteiras. Brasília, 1997 (Mestrado em Antropologia Social) Universidade de Brasília.

SANTOS, Sônia Nicolau. À procura da terra perdida. Para uma reconstituição do conflito de Cachoeirinha. Belo Horizonte: s/e. s/d (mimeo).

SENNA, Nelson de. A Terra Mineira. Chorografia do Estado de Minas Gerais. 2 Ed. Belo Horizonte: Imprensa Oficial, 1926. 2 Volumes.

SILVA, Paulo Robério Ferreira. Manga - Encontro com a modernidade: permanências e rupturas nos modos de vida (1936-1958). Manga: Sapiens, 2010.

SPIX, J. B. von e MARTIUS, C. F. P. Von. Viagem pelo Brasil. 1817-1820. 3 ed. São Paulo: Melhoramentos; Brasília: Instituto Nacional do Livro, 1976. 3 volumes.

SOUZA, Candice Vidal e. A Pátria Geográfica. Sertão e Litoral no Pensamento Social Brasileiro. Goiania: EdUFG, 1997.

SOUZA, Jessé de. A elite do atraso: da escravidãoà Lava Jato. Rio de Janeiro: Leya, 2017.

TAUNAY, Affonso de Escragnolle. História Geral das Bandeiras Paulistas. São Paulo: Imprensa Oficial, 1948, 11 volumes.

VIANA, Urbino. Bandeiras e Sertanistas Baianos. São Paulo: Nacional, 1935. Brasiliana, Vol. 48.

VIANNA, Nelson. Foiceiros e vaqueiros. Rio de Janeiro: Poncetti, 1956. 
VELLOSO, Antônio Augusto. Colonização Nacional da Jahyba. Em Revista do Arquivo Público Mineiro. Anno VI, pp. 1017-1025, 1901.

VEIGA, José Pedro Xavier da. Ephemerides mineiras: 1664-1687. Ouro Preto: Imprensa Oficial de Minas Gerais, 1897.

WELLS, James Willians. Exploring and Travelling Three Thousand Miles trough Brazil, from Rio de Janeiro to Maranhão: London: Sampson Low, Marston, Searle \& Rivington, 1886. 2 vs. 